\title{
Genetic Analysis of Synaptotagmin C2 Domain Specificity in Regulating Spontaneous and Evoked Neurotransmitter Release
}

\author{
Jihye Lee, Zhuo Guan, Yulia Akbergenova, and J. Troy Littleton \\ The Picower Institute for Learning and Memory, Department of Biology, Department of Brain and Cognitive Sciences, Massachusetts Institute of \\ Technology, Cambridge, Massachusetts 02139
}

\begin{abstract}
Synaptic vesicle fusion mediates communication between neurons and is triggered by rapid influx of $\mathrm{Ca}^{2+}$. The $\mathrm{Ca}^{2+}$-triggering step for fusion is regulated by the synaptic vesicle transmembrane protein Synaptotagmin 1 (Syt1). Syt1 contains two cytoplasmic C2 domains, termed $\mathrm{C} 2 \mathrm{~A}$ and $\mathrm{C} 2 \mathrm{~B}$, which coordinate $\mathrm{Ca}^{2+}$ binding. Although $\mathrm{C} 2 \mathrm{~A}$ and $\mathrm{C} 2 \mathrm{~B}$ share similar topology, binding of $\mathrm{Ca}{ }^{2+}$ ions to the $\mathrm{C} 2 \mathrm{~B}$ domain has been suggested as the only critical trigger for evoked vesicle release. If and how $\mathrm{C} 2 \mathrm{~A}$ domain function is coordinated with $\mathrm{C} 2 \mathrm{~B}$ remain unclear. In this study, we generated a panel of Syt 1 chimeric constructs in Drosophila to delineate the unique and shared functions of each $\mathrm{C} 2$ domain in regulation of synaptic vesicle fusion. Expression of Syt 1 transgenes containing only individual C2 domains, or dual $\mathrm{C} 2 \mathrm{~A}-\mathrm{C} 2 \mathrm{~A}$ or $\mathrm{C} 2 \mathrm{~B}-\mathrm{C} 2 \mathrm{~B}$ chimeras, failed to restore Syt 1 function in a syt $1^{-1-}$ null mutant background, indicating both $\mathrm{C} 2 \mathrm{~A}$ and $\mathrm{C} 2 \mathrm{~B}$ are specifically required to support fast synchronous release. Mutations that disrupted $\mathrm{Ca}^{2+}$ binding to both $\mathrm{C} 2$ domains failed to rescue evoked release, but supported synaptic vesicle docking and endocytosis, indicating that these functions of Syt 1 are $\mathrm{Ca}^{2+}$-independent. The dual C2 domain $\mathrm{Ca}^{2+}$-binding mutant also enhanced spontaneous fusion while dramatically increasing evoked release when coexpressed with native Syt1. Together, these data indicate that synaptic transmission can be regulated by Syt 1 multimerization and that both $\mathrm{C} 2$ domains of Syt1 are uniquely required for modulating $\mathrm{Ca}^{2+}$-independent spontaneous fusion and $\mathrm{Ca}^{2+}$-dependent synchronous release.
\end{abstract}

\section{Introduction}

Neurotransmitter release at synapses occurs within milliseconds following $\mathrm{Ca}^{2+}$ influx through voltage-gated channels (Llinás et al., 1981; Neher and Zucker, 1993; Sabatini and Regehr, 1996; Sun and Wu, 2001; Wojcik and Brose, 2007). Although the full complement of $\mathrm{Ca}^{2+}$ binding proteins that coordinate synaptic vesicle fusion is unknown, the synaptic vesicle protein Synaptotagmin 1 (Syt1) has emerged as a key $\mathrm{Ca}^{2+}$ sensor that regulates fast synchronous release. Syt1 consists of a short intraluminal $\mathrm{N}$-terminal region, a single transmembrane domain, and two cytoplasmic PKC-homologous repeats (C2 domains) that bind $\mathrm{Ca}^{2+}$ via negatively charged aspartate residues (Perin et al., 1990; Perin et al., 1991; Sutton et al., 1995; Ubach et al., 1998; Desai et al., 2000). In vitro studies have demonstrated $\mathrm{Ca}^{2+}$-dependent interactions between Syt1 and plasma membrane phospholipids (Brose et al., 1992; Chapman and Jahn,

\footnotetext{
Received July 6, 2012; revised 0ct. 11, 2012; accepted Nov. 12, 2012.

Author contributions: J.L. and J.T.L. designed research; J.L., Z.G., and Y.A. performed research; J.L. and Y.A. analyzed data; J.L. and J.T.L. wrote the paper.

This work was supported by NIH Grant NS40296 to J.T.L. We thank the Bloomington Stock Center for Drosophila strains.

The authors declare no competing financial interests.

Correspondence should be addressed to Dr. Jihye Lee, The Picower Institute for Learning and Memory, Massachusetts Institute of Technology, 43 Vassar Street, Building 46, Room 3251, Cambridge, MA 02139. E-mail: jihyelee@mit.edu.

DOI:10.1523/JNEUROSCI.3214-12.2013

Copyright $\odot 2013$ the authors $\quad 0270-6474 / 13 / 330187-14 \$ 15.00 / 0$
}

1994; Sutton et al., 1995; Fernandez et al., 2001), as well as the neuronal SNARE complex (Chapman et al., 1995; Zhang et al., 2002). The loss of Syt1 severely impairs $\mathrm{Ca}^{2+}$-dependent synchronous vesicle release (Geppert et al., 1994; Geppert et al., 1997; Voets et al., 2001; Yoshihara and Littleton, 2002; Nishiki and Augustine, 2004b; Liu et al., 2009).

To determine how Syt1 regulates fusion, several studies have focused on the function of its two C2 domains, termed C2A and C2B. Despite the robust interaction between the C2A domain and membrane phospholipids (Chapman and Davis, 1998; Bai et al., 2000; Bai et al., 2002; Stevens and Sullivan, 2003; Paddock et al., 2008), neutralization of negatively charged aspartate residues (D to $\mathrm{N}$ ) in C2A does not disrupt synchronous neurotransmitter release (Fernández-Chacón et al., 2002; Robinson et al., 2002; Stevens and Sullivan, 2003). In contrast, a D229E substitution in the Drosophila C2A domain reduced vesicle fusion (Striegel et al., 2012), whereas neutralization of D232 (D232N) in mice enhanced synaptic transmission (Fernández-Chacón et al., 2002; Stevens and Sullivan, 2003; Pang et al., 2006a). Together, these results suggest that the $\mathrm{C} 2 \mathrm{~A}$ domain may regulate exocytosis, but its specific function remains unclear. In contrast to $\mathrm{C} 2 \mathrm{~A}, \mathrm{Ca}^{2+}$ binding to the $\mathrm{C} 2 \mathrm{~B}$ domain is required for synchronous release (Littleton et al., 1994; Littleton et al., 2001; Mackler et al., 2002; Nishiki and Augustine, 2004aNishiki and Augustine, 2004b Shin et al., 2009; Yoshihara et al., 2010).

Although these studies emphasize the importance of $\mathrm{Ca}^{2+}$ binding to $\mathrm{C} 2 \mathrm{~B}$, there is no experimental evidence to indicate that 
C2B can function without C2A. Indeed, membrane penetration by Syt1 requires cooperativity between its tandem C2 domains (Bai et al., 2002; Herrick et al., 2006). Here, we tested the function of each C2 domain and identified cooperative actions of C2A and C2B that regulate release at Drosophila neuromuscular junctions (NMJs). We generated transgenic Syt 1 constructs bearing $\mathrm{Ca}^{2+}$ binding mutations in each $\mathrm{C} 2$ domain or that expressed proteins with chimeric $\mathrm{C} 2$ domain structure. Our results indicate that the essential function for the $\mathrm{C} 2 \mathrm{~B}$ domain in fusion requires $\mathrm{C} 2 \mathrm{~A}$. In addition, similar interactions are required for regulation of spontaneous vesicle release, suggesting that Syt 1 C2 domain cooperativity regulates multiple synaptic vesicle release pathways.

\section{Materials and Methods}

Drosophila stocks and genetics. Drosophila melanogaster were cultured on standard medium at $22^{\circ} \mathrm{C}$. Female larvae and adult flies were used for analyses described below unless indicated. DNA constructs for UASsynaptotagmin 1 (syt1) ${ }^{C 2 B-D 3 / 4 N}$ encoding Syt $1^{\mathrm{D} 416 \mathrm{~N}, \mathrm{D} 418 \mathrm{~N}}\left(\mathrm{C} 2 \mathrm{~A}-\mathrm{C} 2 \mathrm{~B}^{\star}\right)$ were obtained from N.E. Reist (Colorado State University, Fort Collins, CO). DNA for UAS-syt1 $1^{\text {C2A-D3/4N }}$ encoding Syt1 ${ }^{\text {D282N, D284N }}\left(\mathrm{C} 2 \mathrm{~A}^{*}-\right.$ $\mathrm{C} 2 \mathrm{~B}$ ) was generated using the QuikChange multiSite-Directed Mutagenesis Kit (Stratagene) with the primer ctcgtgtttgccattttcAacttcAatcgc. A similar strategy was used to generate UAS-syt1 $1^{C 2 A-D 3 / 4 N-C 2 B-D 3 / 4 N}$ $\left(\mathrm{C} 2 \mathrm{~A}^{\star}-\mathrm{C} 2 \mathrm{~B}^{\star}\right)$ encoding Syt1 ${ }^{\mathrm{D} 282 \mathrm{~N}, \mathrm{D} 284 \mathrm{~N}, \mathrm{D} 416 \mathrm{~N}, \mathrm{D} 418 \mathrm{~N}}$. Isolated C2 domain constructs with or without $\mathrm{D} 3 / 4 \mathrm{~N}$ mutations $\left(\mathrm{C} 2 \mathrm{~A}, \mathrm{C} 2 \mathrm{~A}^{\star}, \mathrm{C} 2 \mathrm{~B}\right.$, and $\mathrm{C} 2 \mathrm{~B}^{\star}$ ) were generated by PCR reactions with the following primer sets: cgGAATTCatgccgccaaatgcaaaatcgg $\left(5^{\prime}\right.$-EcoRI) and gcTCTAGAttatccttcaacgctgaccaggtc $\left(3^{\prime}-\mathrm{XbaI}\right)$ for $\mathrm{C} 2 \mathrm{~A}$ and $\mathrm{C} 2 \mathrm{~A}^{*}$; cgGAATTCatgccgccaaatgcaaaatcgg ( $5^{\prime}$-EcoRI), ccgCTCGAGctgcttgtcctcctcgtcaccctc (3'-XhoI for a cytoplasmic linker), gcgCTCGAGagcgttgaaggagagggcggac (5'-XhoI for C2B), and cgTCTAGAttacttcatgttcttcaggatc (3'-XbaI) for $\mathrm{C} 2 \mathrm{~B}$ and $\mathrm{C} 2 \mathrm{~B}^{*}$. In addition, constructs composed of two homologous $\mathrm{C} 2$ domains tagged with hemagglutinin (C2A-C2A and $\mathrm{C} 2 \mathrm{~B}-\mathrm{C} 2 \mathrm{~B})$ were generated by the Drosophila Gateway vector system with the following primer sets: cgGAATTCatgccgccaaatgcaaaatcgg (5'-EcoRI), gaAGATCTcttttcctgtccgccctctccttc ( $3^{\prime}$-BglII for the first C2A), GAagatctCAGAGCGAGCAGAAGctggggc (5'-BglII for the second C2A), tccTCTA GActtttcctgtccgccctctccttc ( $3^{\prime}$-XbaI for the second C2A), CACCatgccgccaaatgcaaaatcg (5'-Gateway), and tccTCTAGActtttcctgtc ( $3^{\prime}$-Gateway) for C2A-C2A; cgGAATTCatgccgccaaatgcaaaatcgg (5'-EcoRI), GAagatctCTTCATGTTCTTCAGGATCTCGTC ( $3^{\prime}$-BglII for the first C2B), GAagatctAGCGTTGAAGGAGAGGGCGGACAG (5'-BglII for the second $\mathrm{C} 2 \mathrm{~B}$ ), tccTCTAGActtcatgttcttcaggatc ( $3^{\prime}$-XbaI for the second $\mathrm{C} 2 \mathrm{~B}$ ), CACCatgccgccaaatgcaaaatcg (5'-Gateway), and tccTCTAGActtcatgttcttc ( $3^{\prime}$-Gateway) for C2B-C2B. Transgenic strains were generated using standard microinjection into white ${ }^{-}$embryos performed by Duke University Model System Genomics (Durham, NC) and Genetics Services (Cambridge, MA). UAS-syt1 transgenes were expressed using a GAL4 driver under the control of the pan-neuronal elav promoter (Campos et al., 1987) in the syt1 null (syt1 ${ }^{-/-}$) background. Null mutants lacking endogenous Sytl were generated by crossing syt1 ${ }^{N 13}$, an intragenic syt1 deficiency (Littleton et al., 1994), with syt $1^{A D 4}$, which truncates Syt 1 before the transmembrane domain (DiAntonio and Schwarz, 1994).

Western blot analysis. Western blots were performed using standard laboratory procedures. Nitrocellulose membranes were probed with mouse anti-Discs-Large (Dlg) (4F3, 1:2000) and rabbit anti-Syt1 antibodies (1:200). The 4F3 antibody was obtained from the Developmental Studies Hybridoma Bank (University of Iowa, Iowa City, IA). Blocking was performed in a solution containing four parts PBS $(4.3 \mathrm{~mm}$ $\mathrm{Na}_{2} \mathrm{HPO}_{4}, 1.5 \mathrm{~mm} \mathrm{KH} \mathrm{PO}_{4}, 137 \mathrm{~mm} \mathrm{NaCl}$, pH 7.4) to one part Odyssey Blocking Buffer (LI-COR Biosciences). Antibody incubations were performed in a solution containing four parts PBST ( $1 \times$ PBS with $1 \%$ Tween 20) to one part Odyssey Blocking Buffer. The probes were detected using AlexaFluor-680-conjugated goat anti-rabbit IgG at a dilution of 1:5000 (Invitrogen) and IR Dye 800-conjugated goat anti-mouse IgG at a dilution of 1:5000 (Invitrogen). Visualization was done using the LI-COR Odyssey Imaging System (LI-COR Biosciences).
Immunohistochemistry. Third instar larvae were reared at $22^{\circ} \mathrm{C}$ and dissected in HL3.1 saline ( $70 \mathrm{~mm} \mathrm{NaCl}, 5 \mathrm{~mm} \mathrm{KCl}, 10 \mathrm{~mm} \mathrm{NaHCO}_{3}, 4 \mathrm{~mm} \mathrm{MgCl}_{2}$, $5 \mathrm{~mm}$ trehalose, $115 \mathrm{~mm}$ sucrose, $5 \mathrm{~mm}$ HEPES, pH 7.2). Larvae were fixed for 20 min in HL3.1 containing 4\% formaldehyde. Following washes, larvae were incubated with primary antibody overnight at $4^{\circ} \mathrm{C}$, incubated with secondary antibodies for $2 \mathrm{~h}$ at room temperature, and mounted in $80 \%$ glycerol for imaging. The dilutions of primary antibodies were as follows: nc82 (1:50) and Syt1 (1:500). The mouse nc82 antibody against Bruchpilot, developed by Erich Buchner, was obtained from the Developmental Studies Hybridoma Bank (University of Iowa, Iowa City, IA). Secondary antibodies from Jackson ImmunoResearch Laboratories, used at a dilution of 1:250, were as follows: FITC-conjugated goat anti-rabbit, FITC-conjugated goat anti-mouse, and rhodamine red/FITCconjugated goat anti-HRP. Visualization was performed with confocal microscopy (Axioplan 2; Carl Zeiss Microscopy) using PASCAL software (Carl Zeiss Microscopy).

Protein expression and protein binding assays. Syt1 was amplified by PCR and subcloned into pGEX-2T. Recombinant Syt1 fused with GST was expressed in Escherichia coli (BL21) and purified using glutathioneSepharose beads (GE Healthcare). A second version of recombinant Syt1 fused with $\mathrm{His}_{6}$ was generated by PCR and subcloning into pTrcHisA, expressed in E. coli (BL21), and purified using the ProBond purification system (Invitrogen). The concentration of purified proteins was determined by SDS-PAGE separation, Coomassie Blue staining, and comparison with BSA standards.

GFP-fused Syt1 fraction was made by freezing 500-1000 male flies in liquid nitrogen. Heads were obtained by sieving and then homogenized on ice in TS buffer supplied with protease inhibitors (cOmplete Mini Protease Inhibitor Cocktail Tablets, Roche Applied Sciences). The homogenate was subsequently solubilized with $0.5 \%$ Triton $\mathrm{X}-100$ for $30 \mathrm{~min}$ at $4^{\circ} \mathrm{C}$. The resulting supernatant (after removing cell debris by centrifugation at $15,000 \times g$ for $20 \mathrm{~min}$ ) was used in binding assays. Protein concentration of head supernatants was measured with Pierce BCA reagents (Thermo Fisher Scientific). GST-fused Syt1 immobilized on glutathione-Sepharose beads was incubated with head supernatants or $\mathrm{His}_{6}$-tagged Syt 1 at $4^{\circ} \mathrm{C}$ for $2 \mathrm{~h}$ in TS buffer containing either $2 \mathrm{~mm}$ EGTA or 1 (or 10$) \mathrm{mm} \mathrm{Ca}^{2+}$. Equal fractions were then subjected to SDS-PAGE and immunoblotting. Polyclonal antiserum against GFP (1:2000; Invitrogen) and Syt1 (1:200) was used for detection of protein binding.

Electron microscopy. Wandering third instar larvae expressing Syt1 transgenic constructs in the wild-type or syt1 $1^{-1-}$ mutant backgrounds were dissected, fixed, and processed as previously described (Rodal et al., 2011), and subjected to a poststaining step with uranyl acetate (2\%; Electron Microscopy Sciences) for electron microscopy. Thin sections $(50 \mathrm{~nm})$ were imaged at a $49,000 \times$ magnification at $80 \mathrm{kV}$ on an electron microscope (Tecnai G2 Spirit, FEI) equipped with a charge-coupled device camera (Advanced Microscopy Techniques). Type $1 \mathrm{~b}$ boutons with small clear vesicles were selected for measurements for the number and diameter of synaptic vesicles.

Electrophysiology. Preparation of wandering third instar larvae and intracellular recordings of excitatory junctional potentials (EJPs) and miniature EJPs (mEJPs) were performed as described previously (Lee et al., 2008) at the indicated extracellular calcium concentrations in HL3.1 saline at muscle fiber 6 of segments A3-A5. All recordings were done using an Axoclamp-2B amplifier (Molecular Devices) and digitized with Digidata 1330 (Molecular Devices). The data were acquired using Axoscope (version 9.0, Molecular Devices) and analyzed using CLAMPFIT (version 9.0, Molecular Devices) and Origin software (version 8.5, Origin Lab). The correction procedure for nonlinear summation of synaptic potential (Martin, 1955) was applied for EJP amplitude comparison when indicated. mEJPs, detected at resting membrane potentials more negative than $-60 \mathrm{mV}$, were analyzed for their frequency and amplitude (MiniAnalysis, Synaptosoft).

\section{Results}

\section{Generation of Syt1 transgenic constructs defective in} $\mathrm{Ca}^{2+}$ binding

It has been well established that five conserved aspartate residues (termed D1-D5) form a $\mathrm{Ca}^{2+}$-binding pocket within each C2 domain (Fig. 1A, asterisks; Shao et al., 1996; Sutton et al., 1999; Fernandez et al., 2001). Neutralization of these residues leads to a 


\section{A}

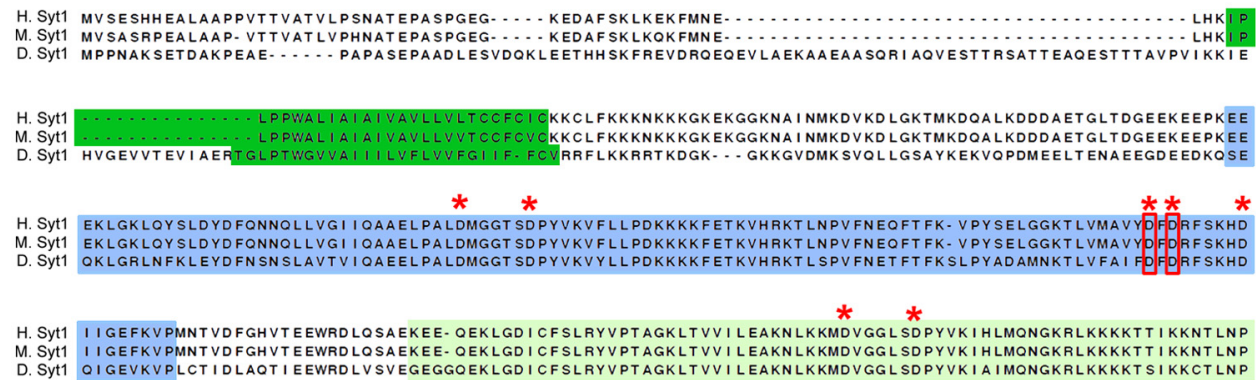

\section{B}
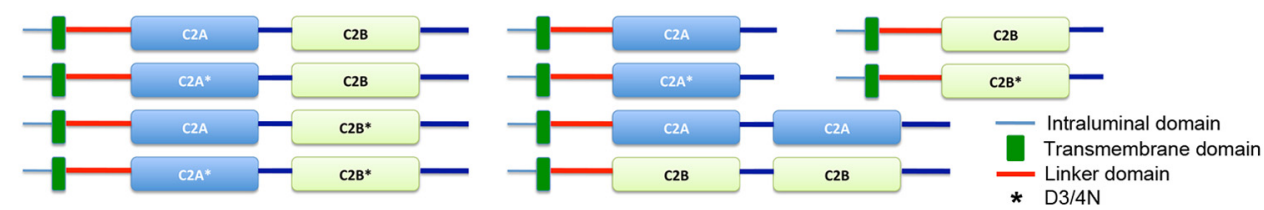

Figure 1. Syt1 transgenic constructs and sequence similarity. $A$, Amino acid sequences of human, mouse, and Drosophila Syt1 are compared. A single transmembrane domain and two $C 2$ domains, $\mathrm{C} 2 \mathrm{~A}$ and $\mathrm{C} 2 \mathrm{~B}$, are indicated as dark green, blue, and light green blocks, respectively. The five aspartate residues (D) involved in binding $\mathrm{Ca}^{2+}$ ions in each $\mathrm{C} 2$ domain are indicated with red

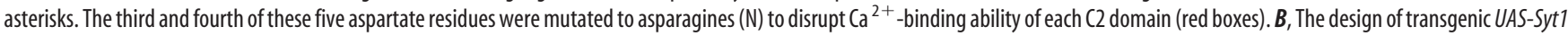
constructs used for the analysis is shown. Syt1 consists of a short intraluminal region (blue line), a single transmembrane domain (dark green box), a cytoplasmic linker (red), two C 2 domains (C2A, blue; (2B, green) with a short linker between them, and a C-terminal tail. ${ }^{*}$ C2 domains containing mutations (described in $A$ ) (red boxes).

loss of $\mathrm{Ca}^{2+}$ binding and subsequent disruption in Syt1 function (Littleton et al., 2001; Fernández-Chacón et al., 2002; Mackler et al., 2002; Stevens and Sullivan, 2003). Although the C2B domain is critical for activating synchronous vesicle release (Littleton et al., 1994; Littleton et al., 2001; Mackler et al., 2002; Nishiki and Augustine, 2004a; Nishiki and Augustine, 2004b Shin et al., 2009; Yoshihara et al., 2010), there are no experimental data to indicate the $\mathrm{C} 2 \mathrm{~B}$ domain can function as the sole $\mathrm{Ca}^{2+}$-binding module independent of $\mathrm{C} 2 \mathrm{~A}$. To delineate isolated functions conveyed by each C2 domain versus cooperative interactions requiring both C2 domains, we generated transgenic Syt1 constructs bearing mutations in the key aspartate residues in each C2 domain in Drosophila (Fig. 1B). The five conserved aspartate residues involved in binding $\mathrm{Ca}^{2+}$ are highly conserved across the phyla (Fig. 1A, asterisks). Similar to prior approaches to eliminate $\mathrm{Ca}^{2+}$ binding (Littleton et al., 2001; Fernández-Chacón et al., 2002; Mackler et al., 2002; Stevens and Sullivan, 2003), two of the five residues in each $\mathrm{C} 2$ domain were mutated to asparagine (Fig. $1 A$, red boxes; D282/284N and in C2A and D416/418N in C2B). This allowed generation of syt1 mutants disrupting $\mathrm{Ca}^{2+}$ binding to $\mathrm{C} 2 \mathrm{~A}, \mathrm{C} 2 \mathrm{~B}$, or both $\mathrm{C} 2$ domains. These mutations (indicated hereafter as $\mathrm{C} 2 \mathrm{~A}^{\star}, \mathrm{C} 2 \mathrm{~B}^{\star}$, or $\mathrm{C} 2 \mathrm{~A}^{\star}-\mathrm{C} 2 \mathrm{~B}^{\star}$ ) were introduced into transgenic constructs (Fig. $1 B$, left) and expressed in the syt 1 null mutant $\left(\right.$ syt1 $\left.{ }^{-/-}\right)$background using the GAL4-UAS system (Brand and Perrimon, 1993).

To begin analyzing these transgenic animals, we first examined expression of the mutant protein in the syt $1^{-1-}$ background to determine whether they localized properly at NMJs, similar to endogenous Syt1. Immunoreactivity against Syt1 indicated that the mutant proteins were distributed at NMJs in a pattern similar to that of endogenous Syt1 (Fig. 2A), suggesting that $\mathrm{Ca}^{2+}$ binding to the $\mathrm{C} 2$ domains is not required for synaptic targeting of Syt1. To avoid complications in functional analysis that might originate from differential expression of each construct, trans- genic lines with similar expression levels by Western analysis (Fig. $2 B$ ) were chosen for comparison in subsequent experiments.

\section{Essential role of $\mathrm{Ca}^{2+}$ binding to the Syt1 C2B domain for synchronous neurotransmitter release}

To functionally characterize the role of $\mathrm{Ca}^{2+}$ binding to each $\mathrm{C} 2$ domain in neurotransmitter release, we measured nerve-evoked excitatory junction potentials (eEJPs) at third instar NMJs in the presence of low $(0.2 \mathrm{~mm})$ and high $(1.0 \mathrm{~mm})$ external $\left[\mathrm{Ca}^{2+}\right]$ (Fig. $3 A$, upper and lower traces, respectively). We found that synchronous release at lower $\mathrm{Ca}^{2+}$ levels $(0.2 \mathrm{~mm})$ was restored more effectively in null mutants rescued with Syt1 lacking $\mathrm{C} 2 \mathrm{~A} \mathrm{Ca}^{2+}$ binding $\left(\mathrm{C} 2 \mathrm{~A}^{\star}-\mathrm{C} 2 \mathrm{~B}\right)$ than those with full-length wild-type Syt1 (C2A-C2B) (Fig. 3B, left, $p<0.01$ ), similar to observations made at Drosophila embryonic NMJs (Yoshihara et al., 2010). Despite differences in the degree of rescue at a lower $\mathrm{Ca}^{2+}$ level, both C2A-C2B and C2A*-C2B Syt1 constructs restored synchronous release to near wild-type levels at more physiological $\mathrm{Ca}^{2+}$ levels (Fig. 3A, bottom traces in each pair; Fig. 3B, right). However, as previously observed (Littleton et al., 2001; Fernández-Chacón et al., 2002; Mackler et al., 2002; Stevens and Sullivan, 2003), Syt1 with defective $\mathrm{C} 2 \mathrm{~B} \mathrm{Ca}{ }^{2+}$ binding $\left(\mathrm{C} 2 \mathrm{~A}-\mathrm{C} 2 \mathrm{~B}^{\star}\right)$ failed to rescue synchronous release, regardless of the presence of a wild-type or mutated $\mathrm{C} 2 \mathrm{~A}$ domain $\left(\mathrm{C} 2 \mathrm{~A}-\mathrm{C} 2 \mathrm{~B}^{*}\right.$ and $\left.\mathrm{C} 2 \mathrm{~A}^{*}-\mathrm{C} 2 \mathrm{~B}^{*}\right)$ or external $\mathrm{Ca}^{2+}$ concentration $(0.2$ and $1.0 \mathrm{~mm}$ ) (Fig. $3 A, B ; p<0.01$ at 0.2 $\mathrm{mM}\left[\mathrm{Ca}^{2+}\right]$ and $p<0.001$ at $\left.1.0 \mathrm{mM}\right)$. As a result, the ratio of synaptic failure, defined as no detectable eEJP following nerve stimulation, was comparable between $s y t 1^{-/-}$and $\mathrm{C} 2 \mathrm{~A}-\mathrm{C} 2 \mathrm{~B}^{\star}$ or $\mathrm{C}_{2} \mathrm{~A}^{\star}-\mathrm{C} 2 \mathrm{~B}^{*}$ rescued lines (Fig. $3 C$; $p<0.05$ or $p<0.001$ ), whereas failures were absent in $\mathrm{C} 2 \mathrm{~A}^{\star}-\mathrm{C} 2 \mathrm{~B}$ or wild-type Syt 1 rescued larvae at a higher $\mathrm{Ca}^{2+}$ level $(1.0 \mathrm{~mm})$ (Fig. $3 C$ ). Together, these data support the model that $\mathrm{Ca}^{2+}$ binding to $\mathrm{C} 2 \mathrm{~B}$, but not $\mathrm{C} 2 \mathrm{~A}$, is essential for fast synchronous neurotransmitter release. 
Cooperativity between Syt 1 C2

domains in synchronous

neurotransmitter release

Rescue data indicate that the $\mathrm{C} 2 \mathrm{~B}$ domain is the major $\mathrm{Ca}^{2+}$-binding module involved in regulation of synchronous fusion. However, these results do not exclude a contribution from the C2A domain in $\mathrm{C} 2 \mathrm{~B}$-driven $\mathrm{Ca}^{2+}$-dependent exocytosis. Given that mutations in the $\mathrm{C} 2 \mathrm{~B}$ domain $\left(\mathrm{C} 2 \mathrm{~A}-\mathrm{C} 2 \mathrm{~B}^{\star}\right)$ led to a complete failure to rescue, regardless of the presence of a wild-type or $\mathrm{Ca}^{2+}$-binding defective $\mathrm{C} 2 \mathrm{~A}$ domain (Fig. 3, C2A-C2B* and $\left.\mathrm{C}_{2} \mathrm{~A}^{\star}-\mathrm{C} 2 \mathrm{~B}^{\star}\right)$, it is possible that $\mathrm{C} 2 \mathrm{~B}$ functions as a major $\mathrm{Ca}^{2+}$-binding module without a C2A domain present. To assay the function of each C2 domain separately, we created transgenic constructs that deleted the entire $\mathrm{C} 2 \mathrm{~A}$ or $\mathrm{C} 2 \mathrm{~B}$ domain. In addition, we created chimeric transgenic lines that expressed a dual C2A-C2A or C2B-C2B Syt 1 protein where the corresponding endogenous $\mathrm{C} 2 \mathrm{do}$ main was replaced to generate a homologous C2 domain architecture (Fig. 1B, right). A construct lacking the entire $\mathrm{C} 2 \mathrm{~B}$ domain (C2A only) was properly localized at NMJs, albeit at a lower level, when detected with anti-Syt 1 antibodies. However, the counterpart lacking the C2A domain (C2B only) was not recognized by immunocytochemistry (data not shown), possibly because of a lack of antigenicity to $\mathrm{C} 2 \mathrm{~B}$ epitopes with our anti-Syt1 antisera. To circumvent this problem, the dual $\mathrm{C} 2 \mathrm{~A}-\mathrm{C} 2 \mathrm{~A}$ and $\mathrm{C} 2 \mathrm{~B}-\mathrm{C} 2 \mathrm{~B}$ constructs were tagged with hemagglutinin. These constructs were detected at NMJs at similar patterns to endogenous Syt1 when visualized with an anti-hemagglutinin antibody (data not shown).

We first examined whether a functional C2A domain in the absence of $\mathrm{C} 2 \mathrm{~B}$ could restore release in $s y t 1^{-1-}$. Syt 1 transgenes expressing $\mathrm{C} 2 \mathrm{~A}$ in the absence of $\mathrm{C} 2 \mathrm{~B}$ failed to rescue fast synchronous release, even in high extracellular $\left[\mathrm{Ca}^{2+}\right]$ (1.0 mM, Fig. $4 A, B, p<0.001)$. A similar failure to rescue was also observed in the case of Syt 1 transgenes expressing $\mathrm{C} 2 \mathrm{~A}$ that lacks $\mathrm{Ca}^{2+}$ binding ability $\left(\mathrm{C}_{2} \mathrm{~A}^{*}\right.$, data not shown). To determine whether the inability of $\mathrm{C} 2 \mathrm{~A}$ to restore release was due to the lack of a $\mathrm{C} 2 \mathrm{~B}$ domain or simply due to the requirement for the dual C2 domain structure found in all synaptotagmin isoforms (Sudhof and Rizo, 1996), we examined transgenic strains that replaced the C2B domain with a second $\mathrm{C} 2 \mathrm{~A}$ to retain the characteristic twin $\mathrm{C} 2$ domain structure (Figs. $1 B$, right, $4 A$, C2A-C2A). We observed that $\mathrm{C} 2 \mathrm{~A}-\mathrm{C} 2 \mathrm{~A}$ transgenic rescue lines had no ability to restore release, as the amplitude of eEJPs remained similar to that in $s y t 1^{-1-}$ and far below control levels (Fig. $4 B, p<0.001$ ). These data indicate that the $\mathrm{C} 2 \mathrm{~A}$ domain alone, or as a dual $\mathrm{C} 2 \mathrm{~A}-\mathrm{C} 2 \mathrm{~A}$ module, cannot support fast synchronous release.

We next assayed whether $\mathrm{C} 2 \mathrm{~B}$ alone was sufficient to support synchronous release when expressed in $s y t 1^{-1-}$ mutants. Constructs expressing a Syt 1 construct lacking the C2A domain were syt $t^{-/}$
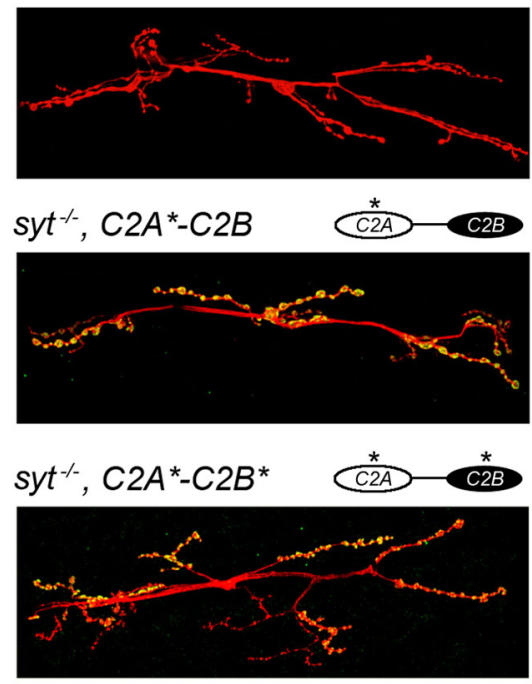

syt $t^{-/-}$

Figure 2. Expression of Syt1 transgenic constructs. $\boldsymbol{A}$, Presynaptic distribution of Syt1 at the third instar larval NMJ is visualized by Syt 1 immunoreactivity (green) in wild-type, syt $1^{-1-}$ (null), and syt $1^{-1-}$ animals rescued with the indicated transgenic

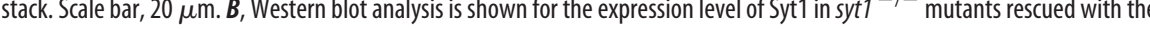
the Discs-large (Dlg) protein are compared as loading controls. Note that the $C 2 \mathrm{~A}^{*}-\mathrm{C} 2 \mathrm{~B}^{*}$ construct results in a change in the size of the protease-sensitive breakdown product previously described (Littleton et al., 1993). $\mathrm{Ca}^{2+}$-binding ability of C2B (Fig. $4 A, B, p<0.001$; data not shown for $\left.\mathrm{C}_{2} \mathrm{~B}^{\star}\right)$. We next examined whether a transgenic protein expressing dual $\mathrm{C} 2 \mathrm{~B}$ domains $(\mathrm{C} 2 \mathrm{~B}-\mathrm{C} 2 \mathrm{~B})$ was able to function in vesicle fusion. Synchronous release in $s y t 1^{-1-}$ larvae expressing this construct was similar to that observed in $s y t 1^{-1-}$ alone (Fig. 4A), indicating that $\mathrm{C} 2 \mathrm{~B}$ cannot function in the absence of C2A (Fig. $4 B, p<0.001$ ). In summary, these data demonstrate that $\mathrm{Ca}^{2+}$-dependent exocytosis mediated by the $\mathrm{C} 2 \mathrm{~B}$ domain requires the presence of $\mathrm{C} 2 \mathrm{~A}$, indicating that the activity of both $\mathrm{C} 2$ domains is specifically required to regulate synchronous synaptic vesicle fusion.

$\mathrm{C} 2 \mathrm{~A}$ and $\mathrm{C} 2 \mathrm{~B}$ function cooperatively to regulate spontaneous neurotransmitter release

In addition to evoked neurotransmitter release, Syt 1 has been shown to regulate spontaneous fusion, as evidenced by the elevated rates of spontaneous release in syt $1^{-1-}$ null mutants (DiAntonio and Schwarz, 1994; Geppert et al., 1994; Littleton et al., 1994; Mackler et al., 2002; Yoshihara and Littleton, 2002; Pang et al., 2006b; Xu et al., 2009). However, the role of the C2A and C2B domains in regulation of spontaneous fusion has just begun to be explored (Xu et al., 2009) and remains poorly characterized. We 

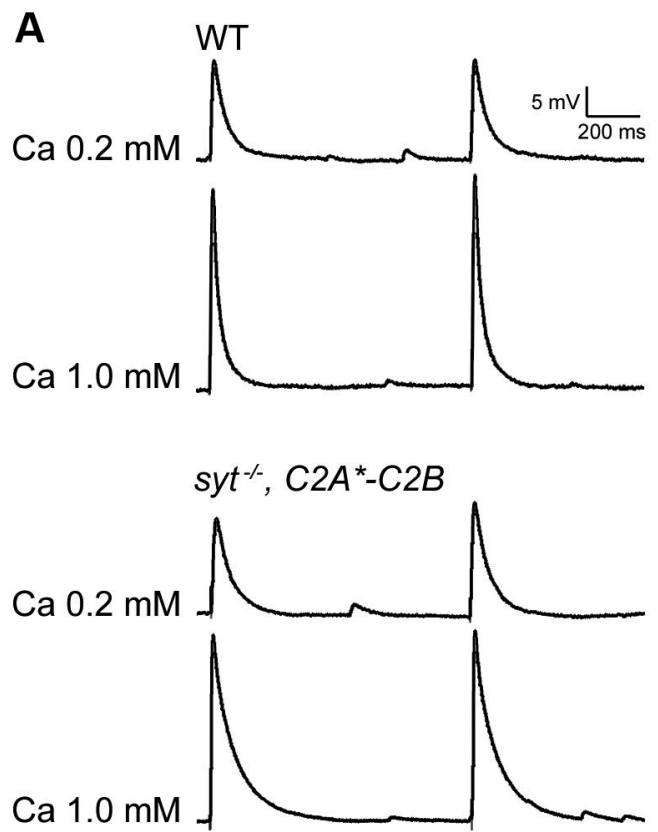

syt $t^{-/}$
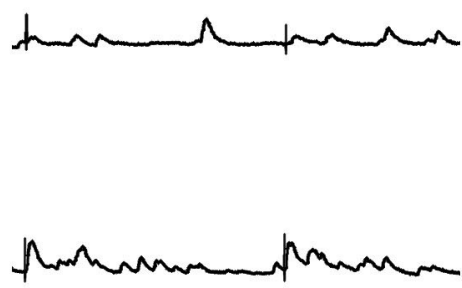

syt $^{-/}, C 2 A-C 2 B^{*}$
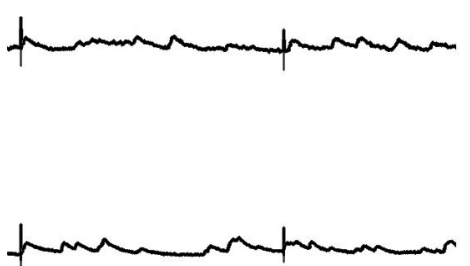

syt $^{-/}, \mathrm{C} 2 \mathrm{~A}-\mathrm{C} 2 \mathrm{~B}$

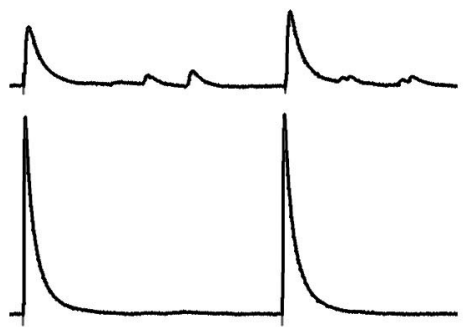

$s y t^{-/-}, C 2 A^{*}-C 2 B^{*}$

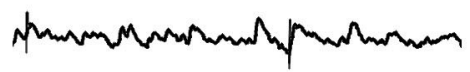

B

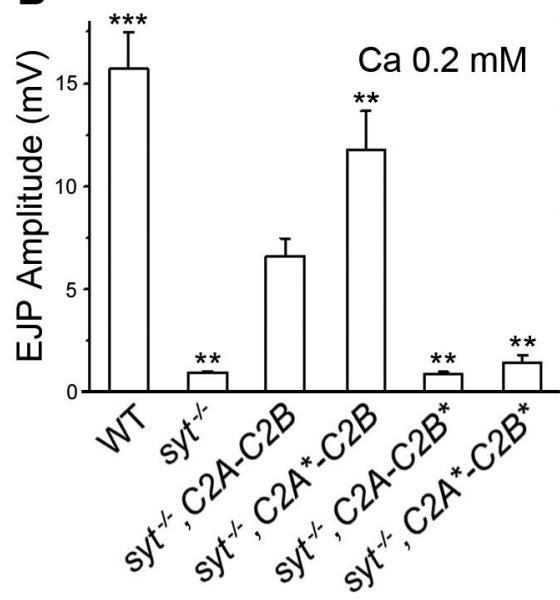

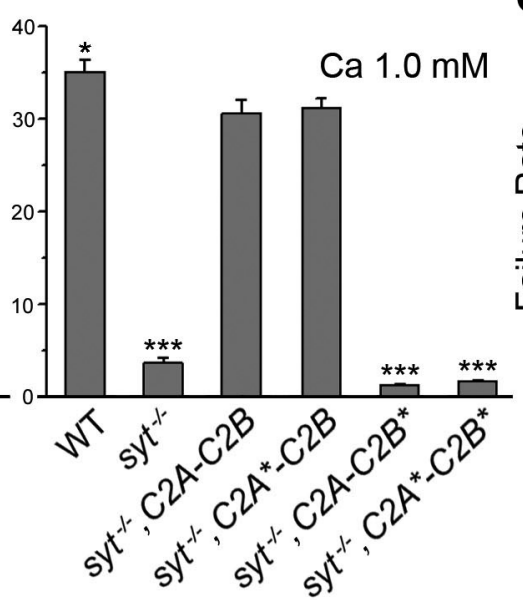

C

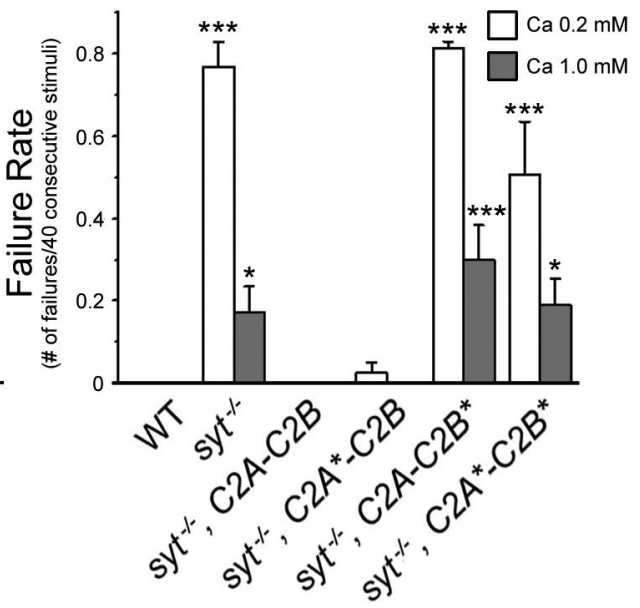

Figure 3. Effects of $\mathrm{Ca}^{2+}$-binding mutations in each Syt1 $\mathrm{C} 2$ domain on evoked synchronous release. $A$, Representative traces of two consecutive eEJP responses are shown for wild-type, syt $1^{-1-}$ (null), and syt $1^{-1-}$ rescued with the indicated transgenic constructs. Example traces are shown for recordings at low (0.2 mM, top) and high (1.0 mm, bottom) [Ca $\left.{ }^{2+}\right]$ in $\mathrm{HL} 3.1$ saline. Calibration: $5 \mathrm{mV}, 200 \mathrm{~ms}$. B, The mean amplitude of EJP responses are summarized for each genotype indicated. C, Failure rates, calculated by counting trials with no detectable eEJP for 40 consecutive stimuli, are shown for each genotype. $B, C$, Data are mean $\pm S$ SEM. ${ }^{* * *} p<0.001,{ }^{* *} p<0.01$, and ${ }^{*} p<0.05$, one-way ANOVA with multiple comparisons using the Fisher's LSD test between syt $1^{-1-}$ rescued with the $\left(2 \mathrm{~A}-\mathrm{C} 2 \mathrm{~B}\right.$ and the indicated genotypes. Number of NMJs examined $\left(0.2\right.$ and $\left.1.0 \mathrm{~mm}\left[\mathrm{Ca}^{2+}\right]_{0}\right): \mathrm{WT}, 7$ and $7 ;$ syt $^{-1-}, 6$ and $16 ;$ syt $^{-1-}, \mathrm{C} 2 \mathrm{~A}-\mathrm{C} 2 \mathrm{~B}, 10$ and 11 ; syt $^{-1-}, \mathrm{C} 2 \mathrm{~A}^{*}-\mathrm{C} 2 \mathrm{~B}, 9$ and $7 ;$ syt $^{-1-}, \mathrm{C} 2 \mathrm{~A}-\mathrm{C} 2 \mathrm{~B}^{*}, 6$ and 10 ; and syt ${ }^{-1-}, \mathrm{C} 2 \mathrm{~A}^{*}-\mathrm{C} 2 \mathrm{~B}^{*}, 6$ and 12.

examined whether $\mathrm{C} 2 \mathrm{~A}$ and $\mathrm{C} 2 \mathrm{~B}$ regulate spontaneous release by measuring mEJP frequency and amplitude in syt $11^{-/-}$larvae rescued with control and mutated transgenic Syt 1 constructs (Fig. 5). Consistent with previous reports, syt $1^{-/-}$mutants displayed a slight but significant increase in the frequency of spontaneous release (Fig. $5 A, B$, bottom, $p<0.05$ ). Expression of the wild-type Syt1 transgene (C2A-C2B) in syt $1^{-1-}$ larvae restored spontaneous release to control levels (Fig. $5 A, B$, bottom). Syt 1 transgenes containing neutralization of two aspartate residues $(\mathrm{D} 3 / 4 \mathrm{~N})$ in $\mathrm{C} 2 \mathrm{~A}\left(\mathrm{C} 2 \mathrm{~A}^{*}-\mathrm{C} 2 \mathrm{~B}\right)$ appeared to be more effective in clamping spontaneous release compared with those rescued with wild-type Syt1, although the effect did not reach statistical significance (Fig. $5 B$, bottom, $p=0.32$ ). In contrast to C2A mutations, mEJP frequency appeared elevated in larvae expressing $\mathrm{Ca}^{2+}$-binding mutations in $\mathrm{C} 2 \mathrm{~B}\left(\mathrm{C} 2 \mathrm{~A}-\mathrm{C} 2 \mathrm{~B}^{*}\right.$ ) (Fig. 5B, bottom, $p=0.14$ ), com- parable to $s y t 1^{-1-}$ (Fig. $5 A, B$, bottom), suggesting that spontaneous release may be differentially regulated by $\mathrm{Ca}^{2+}$-binding to the $\mathrm{C} 2 \mathrm{~A}$ and $\mathrm{C} 2 \mathrm{~B}$ domains.

To determine whether the ability of $\mathrm{C} 2 \mathrm{~B}$ to regulate spontaneous fusion requires wild-type C2A, we assayed Syt 1 transgenes expressing $\mathrm{Ca}^{2+}$ binding mutants in both $\mathrm{C} 2$ domains $\left(\mathrm{C}_{2} \mathrm{~A}^{*}\right.$ $\left.C 2 B^{\star}\right)$. Surprisingly, expression of the $C 2 A^{*}-C 2 B^{\star}$ transgenic rescue in the syt1 $1^{-1-}$ null background induced a dramatic increase in mEJP frequency regardless of external $\left[\mathrm{Ca}^{2+}\right]$ (Fig. $5 A, B$, bottom, $p<0.001)$. The elevated mini-frequency was far beyond the levels observed in $s y t 1^{-/-}$mutants alone or rescue strains expressing C2A-C2B ${ }^{\star}$ (Fig. $5 B, p<0.001, \mathrm{C}_{2} \mathrm{~A}^{\star}-\mathrm{C} 2 \mathrm{~B}^{\star}$ vs syt $1^{-/-}$or $\left.\mathrm{C} 2 \mathrm{~A}-\mathrm{C} 2 \mathrm{~B}^{\star}\right)$.

The increase in spontaneous release induced by expression of a $\mathrm{Ca}^{2+}$-binding defective form of Syt1 could be secondary to 

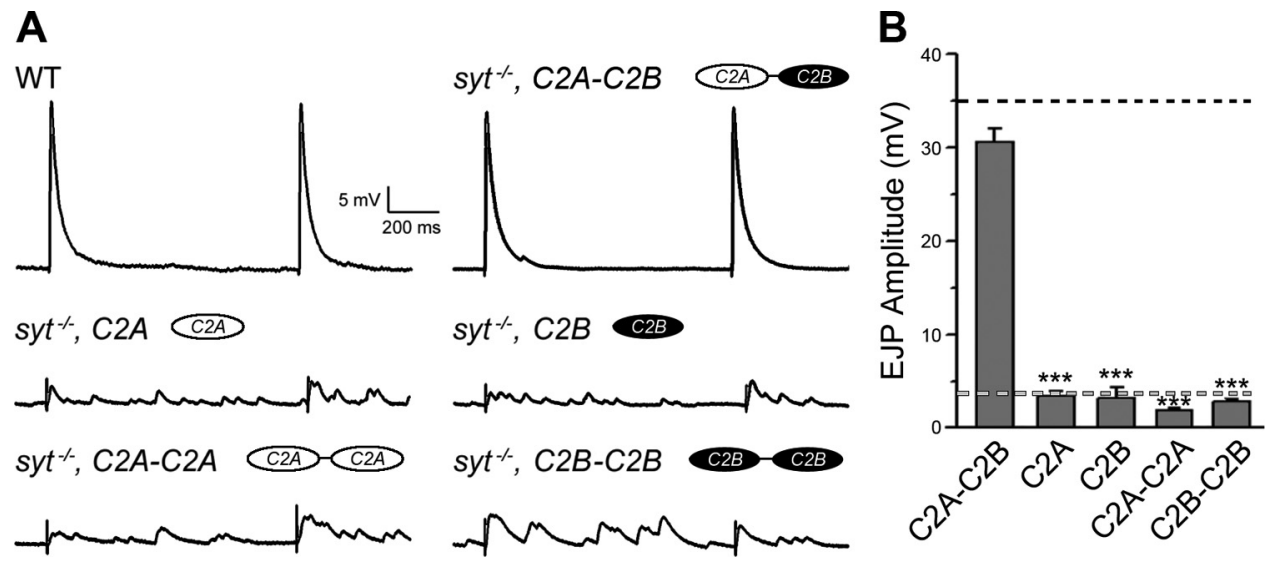

Figure 4. Functional characterization of isolated or dual Syt1 $C 2$ domains on synchronous release. $A$, Representative eEJPs recorded in the presence of high $\left[\mathrm{Ca}^{2+}\right]_{0}(1.0 \mathrm{~mm})$ are shown for wild-type and syt $1^{-1-}$ rescued with the indicated transgenic constructs. $\boldsymbol{B}$, Mean amplitude of eEJP responses are indicated for each genotype. The mean eEJP amplitude for wild-type and syt 1 null mutants (compare Fig. $3 B$ ) are indicated with black and light gray dotted lines, respectively. Data are mean \pm SEM. ${ }^{* * *} p<0.001$, one-way ANOVA with multiple comparisons using the Fisher's LSD

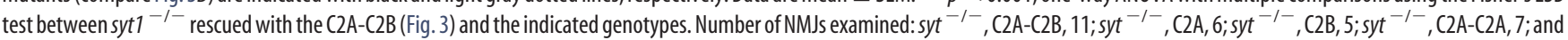
syt $^{-\prime-}$, C2B-C2B, 13.

$\mathrm{Ca}^{2+}$-independent roles for the protein in synaptic vesicle docking, priming, or endocytosis that enhance the number of docked synaptic vesicles. To test this possibility, we examined the distribution of synaptic vesicles in $s y t 1^{-/-}$null mutants expressing $\mathrm{C}_{2} \mathrm{~A}^{*}-\mathrm{C} 2 \mathrm{~B}^{*}$ using transmission electron microscopy and compared them with null mutants alone or rescue lines expressing the wild-type Syt1 protein (C2A-C2B). As previous reports have indicated (Reist et al., 1998; Liu et al., 2009; Young and Neher, 2009), syt1 ${ }^{-1-}$ null mutants displayed a reduction in docked synaptic vesicles (Fig. 6A,D, black column, $p<0.001$ ), as well as a reduced vesicle density, measured as the number of vesicles per unit bouton area (Fig. $6 E, p<0.001$ ). Expression of $\mathrm{C} 2 \mathrm{~A}^{\star}-\mathrm{C} 2 \mathrm{~B}^{\star}$ resulted in an increase in docked synaptic vesicles adjacent to active zones, similar to that in strains expressing the wild-type transgene (Fig. 6A,D, black columns). Likewise, vesicle density in $s y t 1^{-1-}$ mutants expressing $\mathrm{C} 2 \mathrm{~A}^{*}-\mathrm{C} 2 \mathrm{~B}^{\star}$ was comparable to $s y t 1^{-1-}$ animals rescued with the wild-type protein and significantly greater than animals lacking Syt 1 altogether (Fig. $6 E, p<0.001)$. We conclude that a Syt 1 transgene with no $\mathrm{Ca}^{2+}$-binding ability $\left(\mathrm{C} 2 \mathrm{~A}^{*}-\mathrm{C} 2 \mathrm{~B}^{\star}\right)$ can partially rescue defects in synaptic vesicle docking and total vesicle number. Given that docked vesicle number is similar in $s y t 1^{-1-} \mathrm{mu}-$ tants expressing the wild-type or $\mathrm{C} 2 \mathrm{~A}^{\star}-\mathrm{C} 2 \mathrm{~B}^{\star}$ Syt 1 , it is unlikely that structural changes in synaptic vesicle distribution underlie the enhanced spontaneous release induced by $\mathrm{C} 2 \mathrm{~A}^{*}$ $\mathrm{C} 2 \mathrm{~B}^{\star}$ (Fig. $5 \mathrm{~A}, \mathrm{~B}$ ). Rather, $\mathrm{Ca}^{2+}$-binding defective Syt1 appears to increase the fusogenicity of synaptic vesicles, resulting in a dramatic elevation in mEJP frequency.

Because the effects on evoked release suggested cooperative actions of the $\mathrm{C} 2$ domains, we investigated whether such cooperativity between $\mathrm{C} 2$ domains exists for the regulation of spontaneous release. We tested the role of the $\mathrm{C} 2$ domains by measuring mEJP frequency and amplitude in syt $1^{-1-}$ mutants expressing single or dual $\mathrm{C} 2$ domains in either wild-type or mutated form $\left(\mathrm{C} 2 \mathrm{~A}, \mathrm{C} 2 \mathrm{~A}^{*}\right.$, and $\mathrm{C} 2 \mathrm{~A}-\mathrm{C} 2 \mathrm{~A} ; \mathrm{C} 2 \mathrm{~B}, \mathrm{C} 2 \mathrm{~B}^{\star}$, and $\left.\mathrm{C} 2 \mathrm{~B}-\mathrm{C} 2 \mathrm{~B}\right)$. mEJP frequency in larvae expressing transgenic constructs that lack $\mathrm{C} 2 \mathrm{~B}\left(\mathrm{C} 2 \mathrm{~A}, \mathrm{C}_{2} \mathrm{~A}^{*}\right.$, and $\left.\mathrm{C} 2 \mathrm{~A}-\mathrm{C} 2 \mathrm{~A}\right)$ remained comparable with syt $1^{-l-}$ mutants (Fig. 5C,D, gray dashed line) but was still far below the level of those expressing C2A*-C2 $\mathrm{B}^{\star}$ (Fig. $5 D$, black dashed line, $p<0.001)$. Similarly, transgenic constructs consisting solely of the $\mathrm{C} 2 \mathrm{~B}$ domain $\left(\mathrm{C} 2 \mathrm{~B}, \mathrm{C} 2 \mathrm{~B}^{\star}\right.$, and $\left.\mathrm{C} 2 \mathrm{~B}-\mathrm{C} 2 \mathrm{~B}\right)$ failed to rescue the increased mini-frequency in null mutants (Fig. 5C,D) but remained far below the level observed in $s y t 1^{-1-}$ rescued with $\mathrm{C}_{2} \mathrm{~A}^{\star}-\mathrm{C} 2 \mathrm{~B}^{\star}$ (Fig. 5D, $p<0.001$ ). These results indicate that cooperativity between $\mathrm{C} 2 \mathrm{~A}$ and $\mathrm{C} 2 \mathrm{~B}$ is required not only for synchronous neurotransmitter release but also for Syt 1 function as a partial clamp of spontaneous release. It should be noted that there are no observed $\mathrm{Ca}^{2+}$-dependent changes in mEJP frequency within a range $(0.2-2.0 \mathrm{~mm})$ of external $\left[\mathrm{Ca}^{2+}\right]$ at Drosophila NMJs (data not shown), in contrast to the $\mathrm{Ca}^{2+}$. dependent nature of spontaneous release at mammalian synapses (Xu et al., 2009; Kochubey and Schneggenburger, 2011). Thus, it is likely that Syt 1 exerts its function as a partial clamp in a $\mathrm{Ca}^{2+}$. independent manner. Given that $\mathrm{C}_{2} \mathrm{~A}^{*}-\mathrm{C} 2 \mathrm{~B}^{*}$ lacks $\mathrm{Ca}^{2+}$ binding ability and $\mathrm{Ca}^{2+}$-dependent interaction with SNAREs (Earles et al., 2001; Shin et al., 2009), the mutated protein may alter $\mathrm{Ca}^{2+}$-independent interactions of Syt 1 with other partners regulating vesicle release, such as SNAREs and membrane phospholipids. Unlike mEJP frequency, mEJP amplitude remained similar among the different transgenic expressions, except for syt $1^{-1-}$ larvae expressing a C2B-C2B chimeric protein, which significantly enhanced mEJP amplitude (Figs. 5C, 6B, $p<0.001$ ). The increase in mEJP amplitude in C2B-C2B-expressing animals was associated with the appearance of significantly larger synaptic vesicles by transmission electron microscopy (Fig. 6A, arrowheads) and with an increase in diameter of synaptic vesicles near active zones, compared with $s y t 1^{-1-}$ rescued with the wild-type Syt1 (C2A-C2B) (Fig. 6C). Furthermore, we also found a significant reduction in the number of vesicles distant from active zones in $s y t 1^{-1-}$ larvae expressing a C2B-C2B protein (Fig. 6D), resulting in a reduced total vesicle density similar to $s y t 1^{-1-}$ (Fig. $6 E, p<0.001)$. The Syt1 C2B domain is known to interact with several proteins involved in synaptic vesicle endocytosis (Jorgensen et al., 1995; Haucke and De Camilli, 1999; Littleton et al., 2001; Poskanzer et al., 2003; Nicholson-Tomishima and Ryan, 2004; Yao et al., 2012a; Yao et al., 2012b). Considering that the distribution of vesicles near active zones in $s y t 1^{-1-}$ rescued with C2B-C2B was restored to wild-type levels (Fig. 6D, black col$\mathrm{umn}$ ), our findings argue that the $\mathrm{C} 2 \mathrm{~B}-\mathrm{C} 2 \mathrm{~B}$ protein is capable of promoting vesicle docking similar to wild-type Syt1. In contrast, the reduction in total vesicle density, together with the increased vesicle diameter and enlarged mEJP amplitude, indicates that the 
A

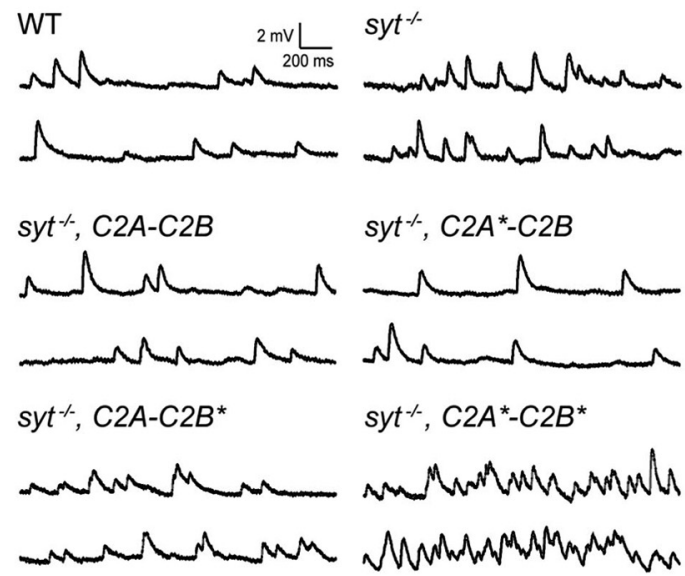

B
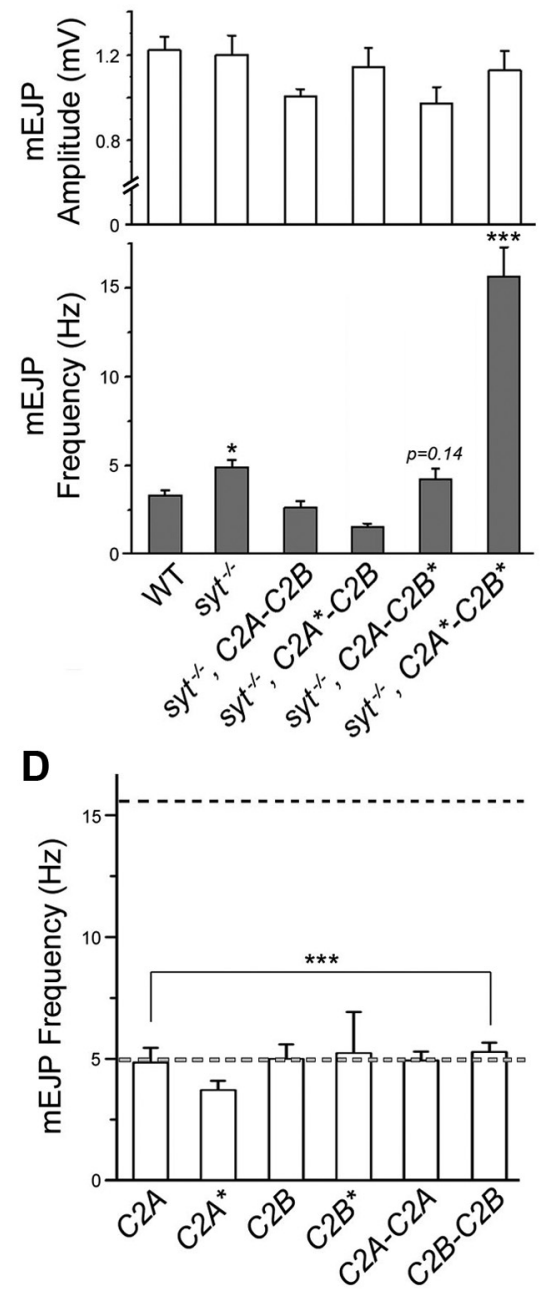

Figure 5. Contributions of Syt1 C 2 domains to spontaneous synaptic release. $A$, Representative $\mathrm{mEJPs}$ recorded in the presence of low $\left[\mathrm{Ca}^{2+}\right]_{0}(0.2 \mathrm{~mm})$ are shown for wild-type, syt $1^{-1-}$ (null), and syt $1^{-1-}$ rescued with the indicated transgenic constructs. Calibration: $2 \mathrm{mV}, 200 \mathrm{~ms}$. B, Summary data for mean mEJP amplitude (top) and frequency (bottom) are shown for the indicated genotypes. Data are mean \pm SEM. ${ }^{* * *} p<0.001$ and ${ }^{*} p<0.05$, one-way ANOVA with multiple comparison using the Fisher's LSD test between syt1 ${ }^{-1-}$ rescued with the C2A-C2B and the

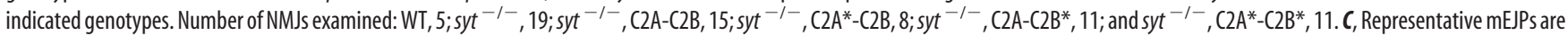
shown for syt $1^{-1-}$ rescued with isolated $C 2$ domains (C2A or $\left.C 2 B\right)$, with or without mutations in $\mathrm{Ca}^{2+}$-binding residues, or with dual C2A (C2A-C2A) or C2B (C2B-C2B) domains. D, Summary of mean $\mathrm{mEJP}$ frequency is shown for the indicated genotypes. The levels measured in syt 1 null mutants (light gray) and syt $1^{-1-}$ rescued with Ca ${ }^{2+}$-binding defective $C 2 A^{*}-C 2 B^{*}$ (black) are indicated with dotted lines. ${ }^{* * *} p<0.001$, one-way ANOVA analysis with multiple comparisons using the Fisher's LSD test between $C 2 A^{*}-C 2 B^{*}$ (black dashed line) and the indicated genotypes. Number of NMJs

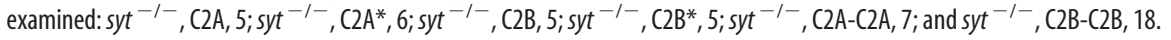

dual C2B-C2B protein likely alters the association of Syt 1 with the endocytotic machinery, resulting in defects in vesicle number and size.

Enhanced neurotransmitter release induced by coexpression of native and $\mathrm{Ca}^{2+}$-insensitive Syt 1

Although expression of transgenic constructs in the $s y t 1^{-/-}$null background allows characterization of their function in the absence of endogenous Syt1, overexpression of these constructs in the wild-type background can assay any dominant-negative or gain-of-function properties of the mutant proteins. Prior work demonstrated that overexpression of the $\mathrm{Ca}^{2+}$ binding $\mathrm{C} 2 \mathrm{~B}$ mutant $\left(\mathrm{C} 2 \mathrm{~A}-\mathrm{C} 2 \mathrm{~B}^{\star}\right)$ induces a decrease in evoked neurotransmitter release at Drosophila larval NMJs (Mackler et al., 2002). We observed a similar effect caused by overexpression of $\mathrm{C} 2 \mathrm{~A}-\mathrm{C} 2 \mathrm{~B}^{*}$ using elav ${ }^{C 155}$-GAL4, which resulted in a significant decrease in eEJP amplitude compared with overexpression of wild-type Syt 1 (C2A-C2B) (Fig. 7A, $p<0.001$ ). Such dominant-negative effects on synchronous release were accompanied by an increase in asynchronous release (Fig. 7A, arrows) and enhanced spontaneous fusion (Fig. $7 B$, bottom), presumably because of the altered nature of the mutated Syt $1 \mathrm{C} 2 \mathrm{~B}$ domain interaction with membrane phospholipids (Paddock et al., 2011).

Whereas overexpression of wild-type or $\mathrm{C} 2 \mathrm{~A} \mathrm{Ca}^{2+}$ binding Syt1 mutants $\left(\mathrm{C} 2 \mathrm{~A}^{*}-\mathrm{C} 2 \mathrm{~B}\right)$ did not alter EJP amplitude at $0.2 \mathrm{~mm}$ extracellular $\left[\mathrm{Ca}^{2+}\right]$, overexpression of the $\mathrm{C}_{2} \mathrm{~A}^{\star}-\mathrm{C} 2 \mathrm{~B}^{\star}$ protein that completely lacks $\mathrm{Ca}^{2+}$-binding ability induced a dramatic increase in EJP amplitude (Fig. $7 A, p<0.001$ ) without affecting asynchronous release or spontaneous fusion (Fig. $7 B$ ). Such enhancement in synchronous release could reflect an increase in the number of synaptic vesicles available for immediate release. To test this hypothesis, we examined the synaptic ultrastructure of larvae expressing wild-type or $\mathrm{C} 2 \mathrm{~A}^{\star}-\mathrm{C} 2 \mathrm{~B}^{\star}$ Syt1 (Fig. $8 A, B$ ). We found no discernible abnormalities associated with overexpression of $\mathrm{C}_{2} \mathrm{~A}^{*}-\mathrm{C} 2 \mathrm{~B}^{*}$, including no significant increase in the number of synaptic vesicles near active zones (Fig. $8 B$ ). Indeed, the 
A WT

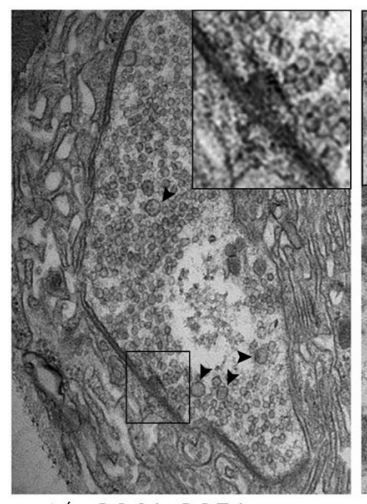

$s y t^{-/}, C 2 A^{*}-C 2 B^{*}$

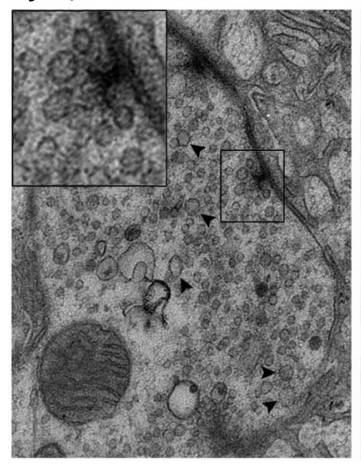

D
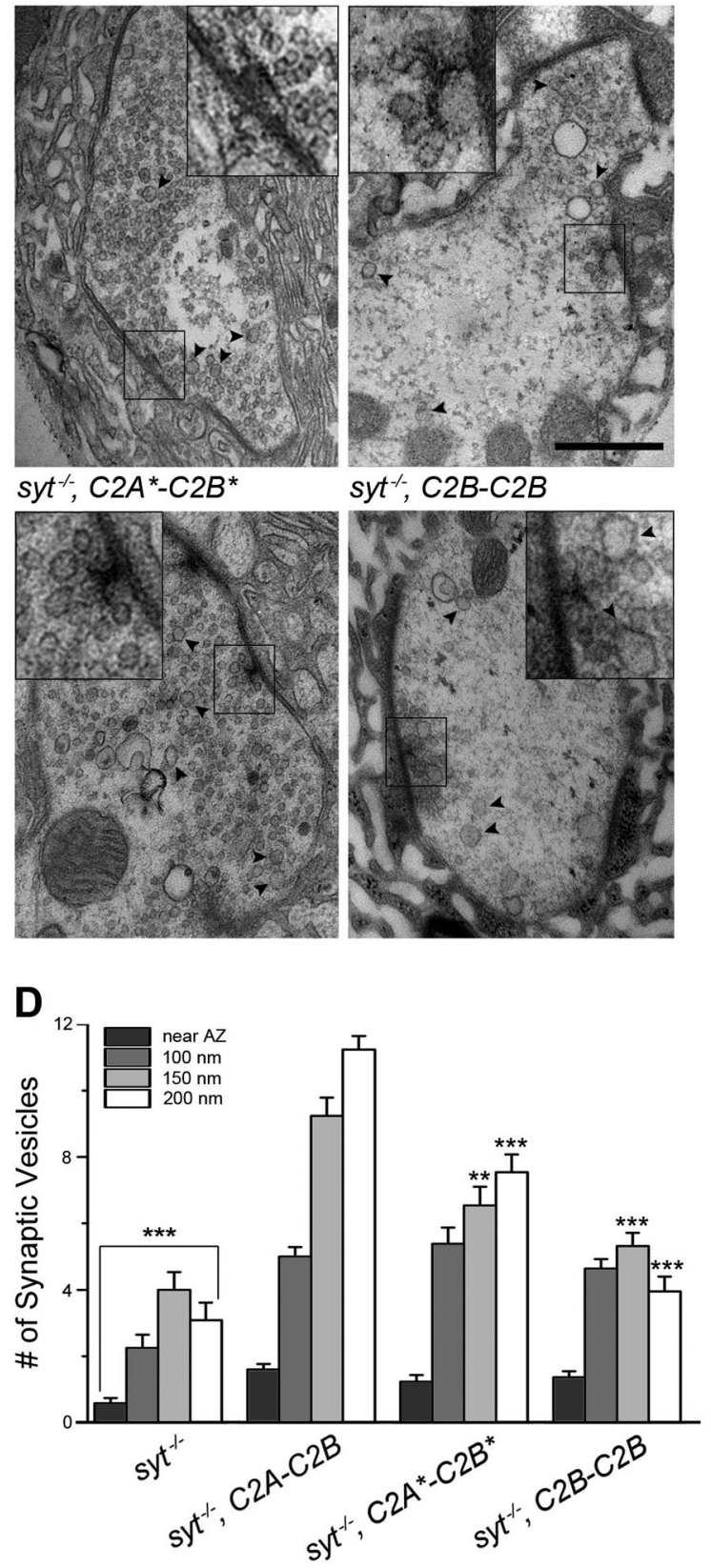
syt $^{-/,}, C 2 B-C 2 B$

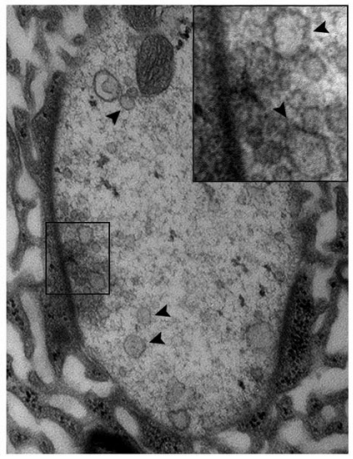

B

E

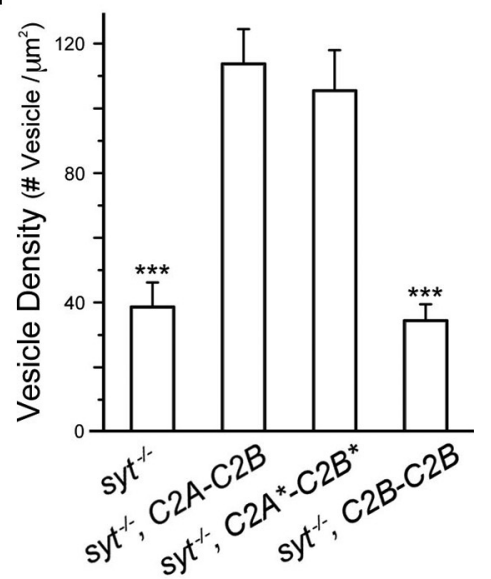

Figure 6. Role of the Syt1 $C 2 B$ domain in regulation of synaptic vesicle size and density. $A$, Electron micrographs are shown for wild-type, syt $1^{-1-}$ (null), and syt $1^{-1-}$ rescued with $\mathrm{Ca}^{2+}$-binding defective $C 2$ domains $\left(C 2 \mathrm{~A}^{*}-\left(2 \mathrm{~B}^{*}\right)\right.$ or with dual $\mathrm{C} 2 \mathrm{~B}$ domains $(C 2 \mathrm{~B}-\mathrm{C} 2 \mathrm{~B})$. Boxed regions in each micrograph are magnified $2.5 \times$ in insets. Synaptic vesicles with abnormally large diameters are indicated with arrowheads. Scale bar, $500 \mathrm{~nm}$. B, Summary of the mean mEJP amplitude is shown for syt $1^{-1-}$ as well as syt1 ${ }^{-1-}$ rescued with wild-type Syt1 (C2A-C2B), $\mathrm{Ca}^{2+}$-binding defective $\left(2 \mathrm{~A}^{*}-\mathrm{C} 2 \mathrm{~B}^{*}\right.$, or dual $\mathrm{C} 2 \mathrm{~A} / \mathrm{C} 2 \mathrm{~B}$ domains. Data for syt $1^{-1-}$ as well as syt $1^{-1-}, \mathrm{C} 2 \mathrm{~A}-\mathrm{C} 2 \mathrm{~B}$ and syt $1^{-1-}, \mathrm{C} 2 \mathrm{~A}^{*}-\mathrm{C} 2 \mathrm{~B}^{*}$ from Figure 5 are presented for comparison. Data are mean \pm SEM. ${ }^{* * *} p<0.001$ and ${ }^{*} p<0.05$, one-way ANOVA with multiple comparisons using the Fisher's LSD test between syt ${ }^{-/-}$rescued with the C2A-C2B and the indicated genotypes. The number of NMJs examined for each genotype is listed in Figure 5. C, Cumulative diameter distributions of synaptic vesicles residing within a $100 \mathrm{~nm}$ radius of active zones are shown for syt ${ }^{-1-}$ as well as those rescued with wild-type, $\mathrm{Ca}^{2+}$-binding defective $(2$ domains, or dual $\mathrm{C} 2 \mathrm{~B}$ domains. A boxed inset is provided for a detailed comparison. $\boldsymbol{D}, \boldsymbol{E}$, The number of synaptic vesicles near or in the vicinity of active zones $(\boldsymbol{D})$ and total synaptic vesicle density $(\boldsymbol{E})$ are summarized for each genotype indicated. Data are mean \pm SEM. ${ }^{* * *} p<0.001$ and ${ }^{* *} p<0.01$, one-way ANOVA with multiple comparisons using the Fisher's LSD test between syt $1^{-1-}$ rescued with the C2A-C2B and the indicated genotypes. Number of active zones analyzed for $D$ and $E$ : syt ${ }^{-1-}, 24$ and $14 ;$ syt $^{-1-}$, C2A-C2B, 17 and $14 ;$ syt $^{-1-}, C 2 A^{*}-C 2 B^{*}, 13$ and 5 ; and syt ${ }^{-1-}$, C2B-C2B, 22 and 14.

total number of synaptic vesicles residing within a $200 \mathrm{~nm}$ radius of active zones was mildly reduced in larvae overexpressing $\mathrm{C}_{2} \mathrm{~A}^{\star}-\mathrm{C} 2 \mathrm{~B}^{\star}$ compared with wild-type Syt1 (Fig. $8 B, p=0.10$ ), suggesting that the enhanced synchronous release is not secondary to increases in docked vesicles. Another possibility for the enhanced evoked release induced by $\mathrm{C} 2 \mathrm{~A}^{*}-\mathrm{C} 2 \mathrm{~B}^{\star}$ would be an increase in the number of release sites. However, there was no significant change in the number of release sites when visualized by immunoreactivity against the active zone protein Bruchpilot (Fig. $8 C, D$ ), indicating that structural changes are unlikely to contribute to the increased synchronous release upon overexpression of $\mathrm{C} 2 \mathrm{~A}^{\star}-\mathrm{C} 2 \mathrm{~B}^{\star}$.

We next investigated which functional aspects of the release process were modified by overexpression of $\mathrm{C} 2 \mathrm{~A}^{\star}-\mathrm{C} 2 \mathrm{~B}^{\star}$. For in- 
A
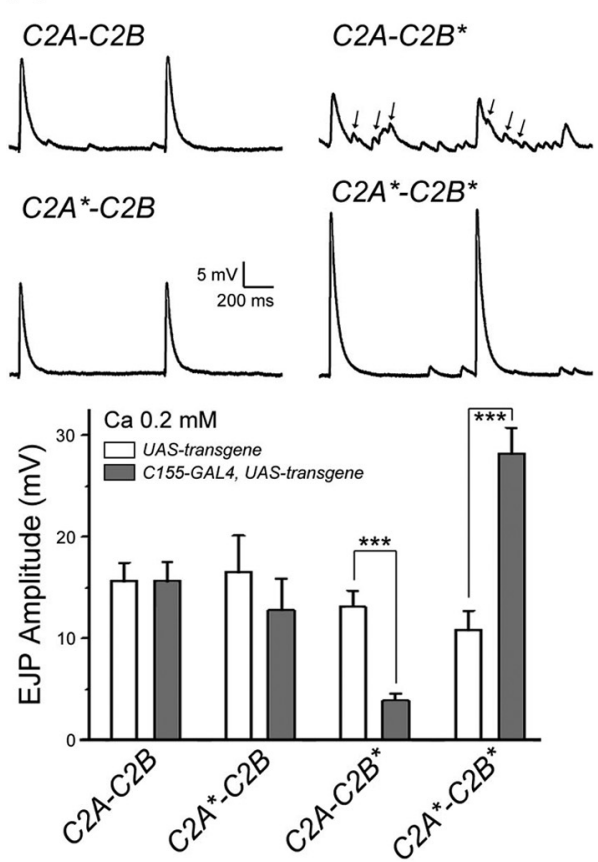

C

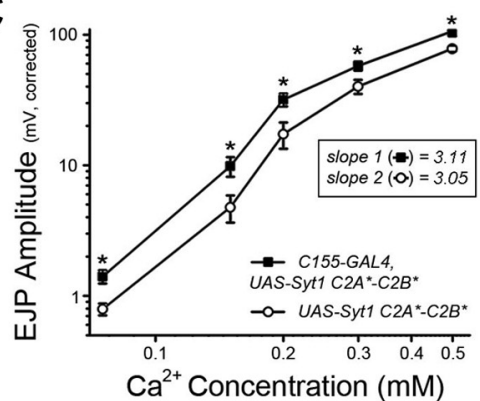

B
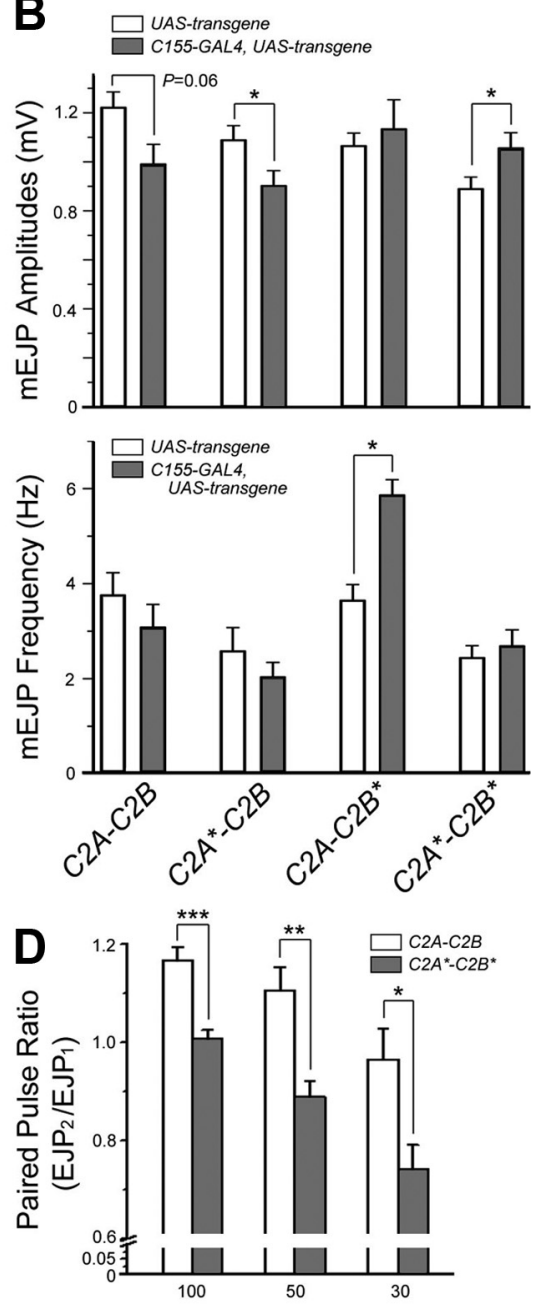

Inter-Stimulus Interval (ms)

Figure 7. Interplay between endogenous and transgenic Syt 1 constructs on evoked synchronous release. $\boldsymbol{A}$, Top, Representative traces of two consecutive EJPs recorded in the presence of low $\left[\mathrm{Ca}^{2+}\right]_{0}(0.2 \mathrm{~mm})$ are shown for wild-type larvae overexpressing the indicated transgenic Syt 1 constructs. Calibration: $5 \mathrm{mV}, 200 \mathrm{~ms}$. Asynchronous release events during stimulation are indicated with arrows. (Bottom) Mean eEJP amplitude is summarized for the indicated genotypes. Animals carrying each transgenic construct without a GAL4-driver (white) served as controls for comparison with the same transgenic constructs driven by elav ${ }^{175}$-GAL4 (gray). $\boldsymbol{B}$, Mean mEJP amplitude (top) and frequency (bottom) are summarized for the indicated genotypes. $\boldsymbol{A}, \boldsymbol{B}$, Number of NMJs examined (control and transgene expression): $\mathrm{C} 2 \mathrm{~A}-\mathrm{C} 2 \mathrm{~B}, 7$ and $8 ; \mathrm{C} 2 \mathrm{~A}^{*}-\mathrm{C} 2 \mathrm{~B}, 8$ and 5; $\mathrm{C} 2 \mathrm{~A}-\mathrm{C} 2 \mathrm{~B}^{*}, 11$ and 8 ; and $\mathrm{C} 2 \mathrm{~A}^{*}-\mathrm{C} 2 \mathrm{~B}^{*}, 10$ and 11. C, Log-log plot for eEJP amplitudes at varying $\left[\mathrm{Ca}^{2+}\right]_{0}$ is shown for animals overexpressing the $C 2 A^{*}-C 2 B^{*}$ construct $(\square)$ and its transgenic control without a GAL4-driver $(\bigcirc)$. The slope values calculated from a linear fit of the first three data points $\left(0.075-0.2 \mathrm{~mm}\left[\mathrm{Ca}^{2+}\right]_{0}\right)$ are indicated in the box. Number of NMJs examined (control and transgene expression): 7 and 11 at 0.075 $\mathrm{mm}\left[\mathrm{Ca}^{2+}\right]_{0} ; 7$ and 11 at $0.15 \mathrm{~mm} ; 6$ and 11 at $0.2 \mathrm{~mm} ; 6$ and 10 at $0.3 \mathrm{~mm}$; and 6 and 9 at $0.5 \mathrm{~mm}$. D. The ratios of eEJP responses in a paired-pulse stimulation paradigm are displayed for wild-type animals overexpressing the C2A-C2B (white) or C2A*-C2B* (gray) constructs. Number of NMJs examined ( $\left(2 \mathrm{~A}-\mathrm{C} 2 \mathrm{~B}\right.$ and $\left(2 \mathrm{~A}^{*}-\mathrm{C} 2 \mathrm{~B}^{*}\right): 8$ and 6 at $30 \mathrm{~ms}$ interval; 8 and 7 at $50 \mathrm{~ms}$; and 8 and 7 at $100 \mathrm{~ms}$. $A-D$, Data are mean \pm SEM. ${ }^{* * *} p<0.001,{ }^{* *} p<0.01$, and ${ }^{*} p<0.05$, Student's $t$ test for control (UAS-transgene) versus neuronal expression (C155-GAL4, UAS-transgene) (A-C) or for neuronal overexpression of C2A-C2B versus C2A*-C2B* (D).

stance, increases in release probability or $\mathrm{Ca}^{2+}$ affinity could result in enhanced synchronous release. We compared these properties in larvae overexpressing $\mathrm{C} 2 \mathrm{~A}^{\star}-\mathrm{C} 2 \mathrm{~B}^{\star}$ with either a transgenic control lacking a GAL4-driver or to larvae overexpressing wild-type Syt1 (C2A-C2B). When eEJP amplitudes were measured at varying external $\left[\mathrm{Ca}^{2+}\right]$, the log-log plot for $\mathrm{Ca}^{2+}$ dependency of release in larvae overexpressing $\mathrm{C}^{2} \mathrm{~A}^{*}-\mathrm{C} 2 \mathrm{~B}^{*}$ was shifted to the left compared with a transgenic control, without a change in the slope (Fig. 7C, $p<0.05$; slope for the control and $\mathrm{C}_{2} \mathrm{~A}^{*}-\mathrm{C} 2 \mathrm{~B}^{*}, 3.05$ and 3.11 , respectively). These data indicate an increase in $\mathrm{Ca}^{2+}$ affinity, but not cooperativity, favoring lower
$\mathrm{Ca}^{2+}$ conditions to support synchronous release. Furthermore, the paired-pulse ratio was significantly reduced in $\mathrm{C} 2 \mathrm{~A}^{*}-\mathrm{C} 2 \mathrm{~B}^{*}-$ overexpressing larvae compared with animals overexpressing wild-type Syt1 (Fig. $7 D)$. Given that the paired-pulse ratio reflects release probability during the first stimulation, these results indicate that overexpression of $\mathrm{C}_{2} \mathrm{~A}^{\star}-\mathrm{C} 2 \mathrm{~B}^{\star}$ enhances synchronous release by increasing release probability and lowering the $\left[\mathrm{Ca}^{2+}\right]$ required to trigger fusion.

\section{Multimerization of native and $\mathrm{Ca}^{2+}$-binding defective Syt1}

Our results demonstrate that expression of a $\mathrm{Ca}^{2+}$-binding defective Syt1 $\left(\mathrm{C}^{2} \mathrm{~A}^{*}\right.$ $\mathrm{C} 2 \mathrm{~B}^{*}$ ) protein in the absence of native Syt1 robustly increases the rate of spontaneous fusion (Fig. 5), without restoring fast synchronous release (Fig. 3). In contrast, coexpression of $\mathrm{C} 2 \mathrm{~A}^{\star}-\mathrm{C} 2 \mathrm{~B}^{\star}$ and native Syt1 resulted in a large enhancement in synchronous release (Fig. $7 A$ ), with no increase in spontaneous fusion (Fig. $7 B$ ). If Syt1 regulates synaptic release as a monomer, we predicted that a mixed population of $\mathrm{Ca}^{2+}$-binding defective and native Syt1 monomers would yield one of several possibilities: (1) both synchronous and spontaneous release would remain unchanged compared with control if native wild-type monomers in a mixed population are sufficient to perform the full repertoire of Sytl functions; (2) synchronous release will be partially disrupted with a slight elevation of spontaneous release if wild-type and $\mathrm{Ca}^{2+}$-binding defective Syt1 monomers participate independently in regulating both synchronous and spontaneous release; or (3) synchronous and spontaneous release will be differentially disrupted if native and mutated Syt1 monomers contribute unequally to different modes of synaptic release, resulting in either relatively normal synchronous release with a slightly enhanced spontaneous release or impaired synchronous release with a wild-type level of spontaneous fusion. However, our results are not consistent with these predictions, given the normal rate of spontaneous release with enhanced synchronous fusion caused by coexpression of $\mathrm{Ca}^{2+}$-binding defective and native Sytl (Fig. $7 A, B$ ). These results suggest the possibility of a Syt1 hetero-multimeric complex where native Syt1 clamps spontaneous release, whereas $\mathrm{C}_{2} \mathrm{~A}^{\star}-\mathrm{C} 2 \mathrm{~B}^{\star}$ Syt1 promotes evoked fusion. Indeed, the synaptotagmin family has been biochemically shown to multimerize in $\mathrm{Ca}^{2+}$-independent (Fukuda et al., 1999; Bai et al., 2000; Fukuda et al., 2001) and $\mathrm{Ca}^{2+}$-dependent manners (Chapman et al., 1996; Damer and Creutz, 1996; Sugita et al., 1996; Osborne et al., 1999; Desai et al., 2000). Thus, we examined whether dimerization could occur between native and $\mathrm{Ca}^{2+}$-insensitive Syt1, 
A $C 2 A-C 2 B$

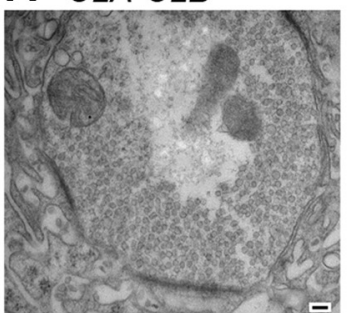

$C 2 A^{*}-C 2 B^{*}$

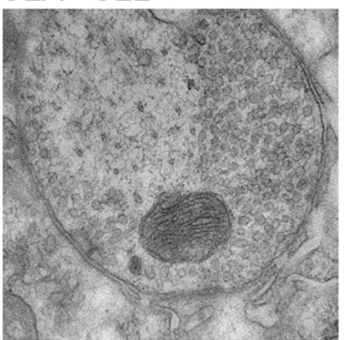

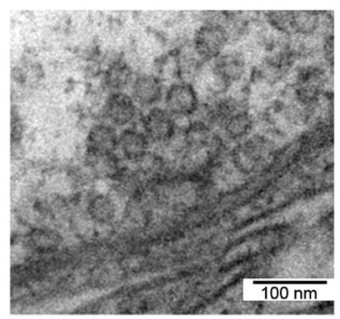

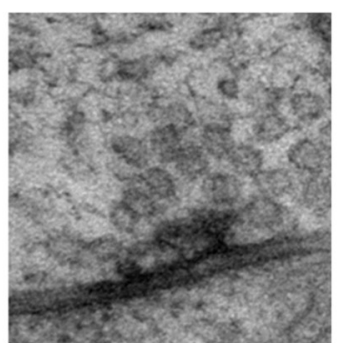

B

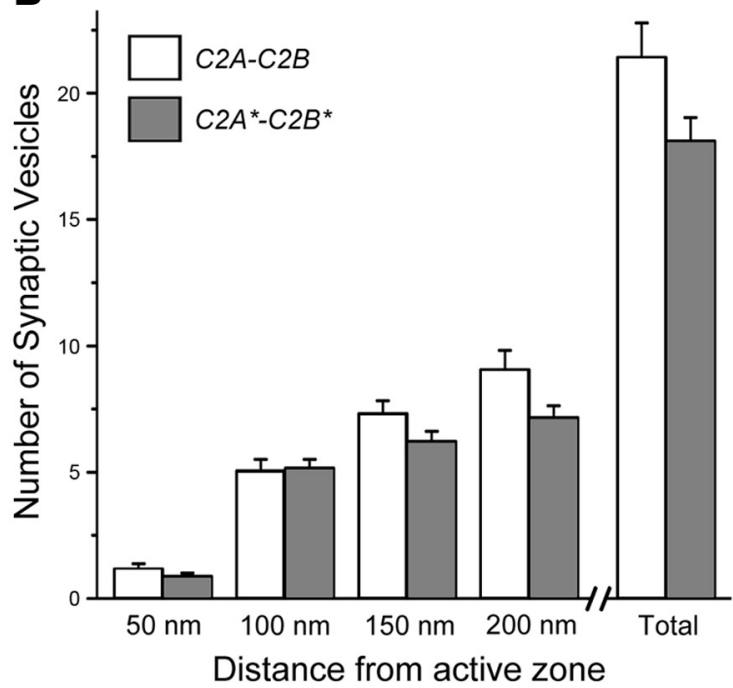

C
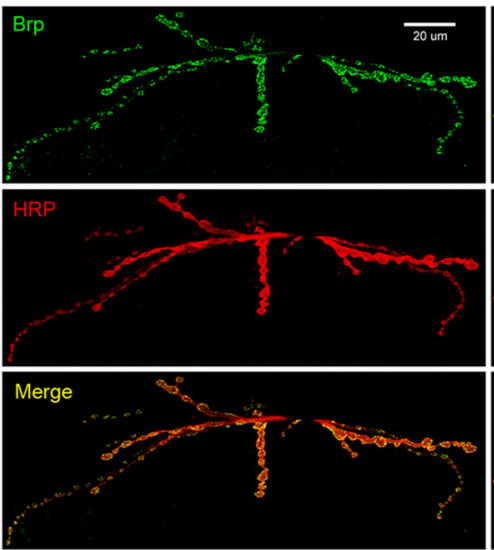

$C 2 A-C 2 B$

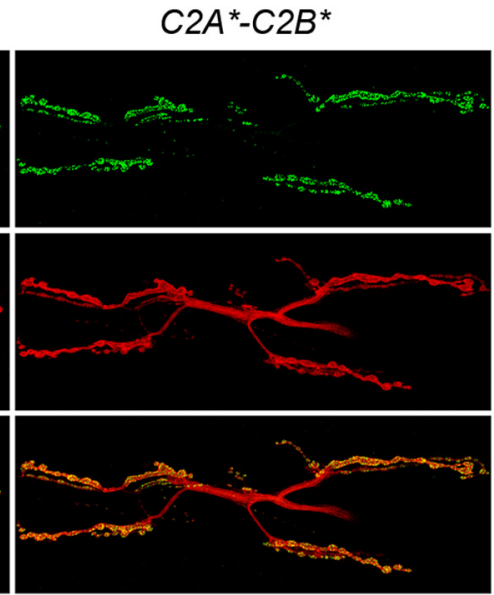

D

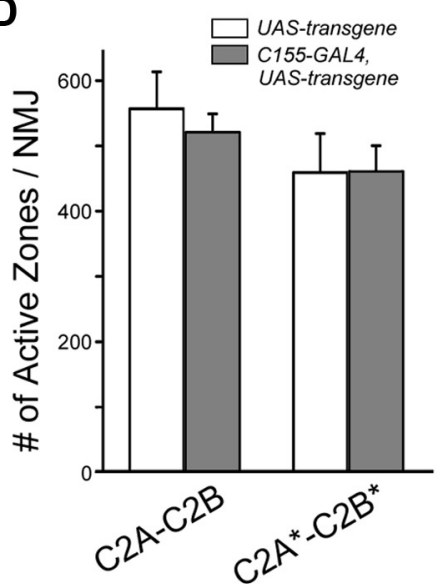

Figure 8. Similar distributions of synaptic vesicles and release sites between animals overexpressing wild-type and $\mathrm{Ca}^{2+}$-binding defective Syt1. $\boldsymbol{A}$, Electron micrographs are shown for larvae overexpressing the wild-type (C2A-C2B, top) or $\mathrm{Ca}^{2+}$-binding defective ( $\left(2 \mathrm{~A}^{*}-\mathrm{C} 2 \mathrm{~B}^{*}\right.$, bottom) Syt1 constructs. Detailed view near a single active zone is shown on the right panels. Scale bar, $100 \mathrm{~nm}$. $\boldsymbol{B}$, Mean number of synaptic vesicles at varying distances from active zones is shown for larvae overexpressing the wild-type or $\mathrm{Ca}^{2+}$-binding defective Syt1 constructs. Number of active zones analyzed (C2A-C2B and $\left(2 A^{*}-\left(2 B^{*}\right): 13\right.$ and 25 at $50 \mathrm{~nm} ; 19$ and 32 at $100-200 \mathrm{~nm} ; 15$ and 16 for total number of synaptic vesicles. C, Representative confocal images depicting distributions of release sites (active zones) in muscle 6/7 NMJs are shown for larvae overexpressing wild-type or $\mathrm{Ca}^{2+}{ }^{2+}$-binding defective Syt1. Active zones are identified by immunoreactivity against Brp (top panels, green). The overall structure of NMJs is detected with HRP immunoreactivity (middle panels, red). The merged images of Brp and HRP channels are shown in the bottom panels. Scale bar, $20 \mu \mathrm{m}$. D , The mean number of active zones per NMJ is summarized for larvae containing each transgenic construct without a GAL 4 driver (white, control) and those with transgenic constructs driven by elav ${ }^{\mathrm{C} 155}$-GAL4 (gray). Number of NMJs examined (control and transgene expression): 12 and 11 for C2A-C2B; 11 and 10 for $C 2 A^{*}-C 2 B^{*}$. B, D, Data are mean \pm SEM.

which might underlie the enhanced synchronous release observed in larvae overexpressing $\mathrm{C} 2 \mathrm{~A}^{\star}-\mathrm{C} 2 \mathrm{~B}^{\star}$.

We purified GFP-tagged full-length Syt 1 expressed in $s y t 1^{-/-}$ fly heads and performed pull-down assays with GST-fused wild-type (GST-C2A-C2B) or mutated (GST-C2A*-C2B ${ }^{\star}$ ) recombinant Syt1 (Fig. 9A). Purified GFP-tagged Syt1 bound to the cytoplasmic C2 domains of Syt1 immobilized on glutathioneSepharose beads in the absence of $\mathrm{Ca}^{2+}$, as visualized by GFP immunoreactivity (Fig. 9A, EGTA, 2 mM). Further multimerization of Syt 1 was observed by increasing $\left[\mathrm{Ca}^{2+}\right]$ to 1 or $10 \mathrm{~mm}$ (Fig. 9A). These $\mathrm{Ca}^{2+}$-independent and $\mathrm{Ca}^{2+}$-dependent interactions did not differ between wild-type and $\mathrm{C} 2 \mathrm{~A}^{\star}-\mathrm{C} 2 \mathrm{~B}^{*}$ Syt1 (Fig. 9A). Similar results were obtained when we performed pulldown assays with His-tagged wild-type cytoplasmic Syt1 C2 domains to bind GST-fused wild-type or mutated recombinant Syt1. $\mathrm{Ca}^{2+}$-independent binding between His-Syt1 and GSTfused Syt1 (wild-type and $\mathrm{C} 2 \mathrm{~A}^{\star}-\mathrm{C} 2 \mathrm{~B}^{\star}$ ) was consistently detected
(Fig. 9B). As seen with endogenous Sytl pull-down, the interaction between His-Syt1 and GST-tagged Syt1 was enhanced in response to $\mathrm{Ca}^{2+}$ (Fig. 9B). Together, these findings indicate that endogenous Syt1 and $\mathrm{Ca}^{2+}$-binding defective Syt1 likely form hetero-multimers in the absence of $\mathrm{Ca}^{2+}$, which enhances the fusogenicity of synaptic vesicles in response to $\mathrm{Ca}^{2+}$ (Fig. 7).

\section{Discussion}

Requirement of tandem Syt1 C2A-C2B domains in regulation of neurotransmitter release

Using transgenic rescue approaches with chimeric Syt 1 proteins, we demonstrate that both the $\mathrm{C} 2 \mathrm{~A}$ and $\mathrm{C} 2 \mathrm{~B}$ domains are individually required for Syt 1 function in regulating vesicle release at the Drosophila NMJ. Prior studies have established that the C2B domain of Syt 1 is a critical module for activating synchronous vesicle release in Drosophila (Littleton et al., 1994; Littleton et al., 2001; Mackler et al., 2002; Yoshihara et al., 2010). In contrast, the 


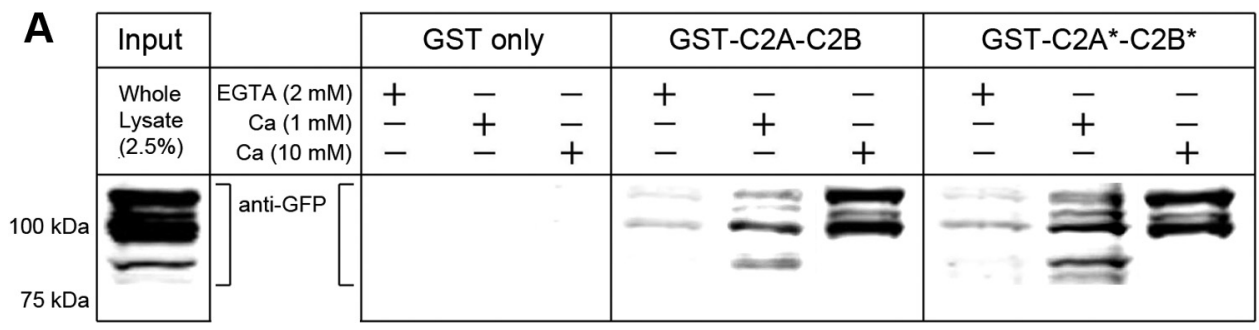

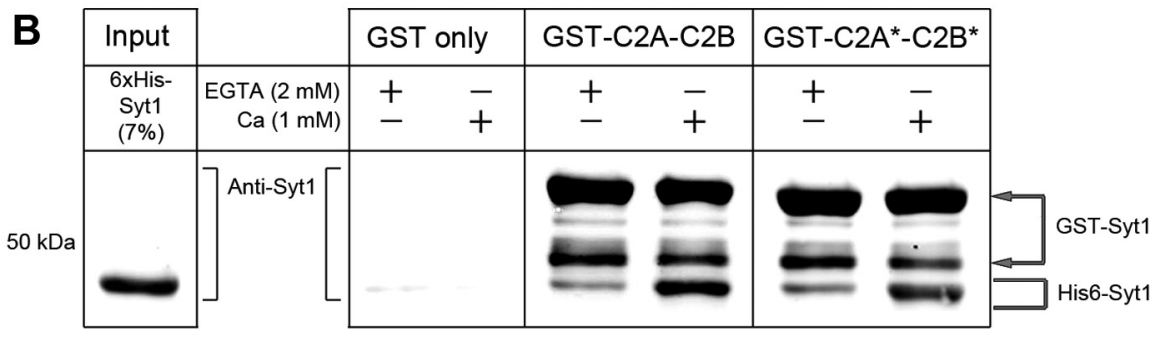

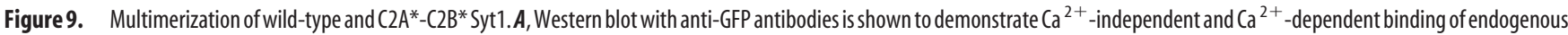
GFP-tagged Syt1, purified from adult head lysates, to GST-fused wild-type (C2A-C2B) or $\mathrm{Ca}^{2+}$-binding defective $\left(C 2 \mathrm{~A}^{*}-\mathrm{C} 2 \mathrm{~B}^{*}\right)$ Syt1. Fly head extracts are incubated with GST-fused Syt1 in the

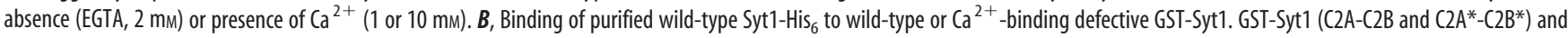
interacting wild-type Syt1-His ${ }_{6}$ products are indicated with arrows (top two bands) and a bracket (a single bottom band), respectively.

contribution of the C2A domain is still being elucidated (Yoshihara et al., 2010; Striegel et al., 2012). Although the activities of isolated C2 domains in their interaction with SNAREs and membrane phospholipids remain controversial in in vitro studies, growing evidence suggests synergistic actions of both $\mathrm{C} 2$ domains. Isolated $\mathrm{C} 2$ domains, either $\mathrm{C} 2 \mathrm{~A}$ or $\mathrm{C} 2 \mathrm{~B}$, bind syntaxin and SNAP-25 less effectively than C2A-C2B constructs in response to $\mathrm{Ca}^{2+}$ in in vitro binding assays (Chapman et al., 1996; Rickman and Davletov, 2003) or reconstituted vesicle fusion assays (Tucker et al., 2004). Synergistic actions of the C2 domains also occur during lipid binding, as isolated C2 domains bind poorly to liposomes made from chromaffin granule lipid extracts compared with dual C2A-C2B proteins (Damer and Creutz, 1994). Likewise, the interaction between the C2B domain and membrane phospholipids requires an intact $\mathrm{C} 2 \mathrm{~A}$ domain, even in the absence of its $\mathrm{Ca}^{2+}$ - and lipid-binding abilities (Bai et al., 2002). Furthermore, $\mathrm{Ca}^{2+}$-dependent penetration of both $\mathrm{C} 2$ domains into reconstituted lipid bilayers appears to occur simultaneously (Hui et al., 2006). These in vitro studies indicate that cooperative actions of C2 domains regulate SNARE and lipid interactions and match our in vivo observations that evoked neurotransmitter release requires both C2 domains of Syt1.

In addition to a dual $\mathrm{C} 2$ domain structure, our findings indicate that $\mathrm{C} 2 \mathrm{~A}$ and $\mathrm{C} 2 \mathrm{~B}$ are uniquely required. Double $\mathrm{C} 2$ domain constructs containing only C2A-C2A fail to restore Syt1 function (Fig. 4), consistent with a lack of $\mathrm{Ca}^{2+}$ dependent binding to t-SNAREs in the absence of C2B (Earles et al., 2001). Similarly, Syt 2 constructs lacking the C2B domain at the calyx of Held failed to support evoked fusion in the null mutant background (Kochubey and Schneggenburger, 2011). Although the $\mathrm{C} 2 \mathrm{~B}$ domain rather than $\mathrm{C} 2 \mathrm{~A}$ plays a more prominent role in evoked fusion (Fig. 3), our results also indicate that the $\mathrm{C} 2 \mathrm{~B}$ domain is not solely responsible for Syt 1 function in synaptic vesicle fusion, as an isolated or dual $\mathrm{C} 2 \mathrm{~B}$ domain cannot support synaptic vesicle fusion (Fig. 4). In addition, dual $\mathrm{C} 2 \mathrm{~B}-\mathrm{C} 2 \mathrm{~B}$ constructs induce additional defects in vesicle endocytosis pathways that increase vesicle size and
mEJP amplitude (Fig. 6). This contrasts with the ability of purified Syt 1 dual C2B domains to induce liposome aggregation and SNARE-dependent vesicle fusion comparable with the wild-type Syt1 (C2A-C2B) in vitro (Hui et al., 2011), indicating a limitation of in vitro fusion assays in recapitulating in vivo requirements for synaptic vesicle release.

\section{Regulation of spontaneous fusion by Syt1 C2 domains}

In addition to triggering synchronous fusion, Syt 1 also partially clamps spontaneous fusion in the absence of a $\mathrm{Ca}^{2+}$ signal. Transgenic constructs with $\mathrm{Ca}^{2+}$ binding mutations in C2A fully rescued the elevated spontaneous fusion rate in syt1 ${ }^{-1-}$ null mutants, whereas those with $\mathrm{Ca}^{2+}$ binding mutations in $\mathrm{C} 2 \mathrm{~B}$ did not (Fig. 5). Prior in vitro studies have demonstrated that $\mathrm{C} 2 \mathrm{~A}^{\star}-\mathrm{C} 2 \mathrm{~B}$ is indistinguishable from wildtype $\mathrm{C} 2 \mathrm{~A}-\mathrm{C} 2 \mathrm{~B}$ in its binding to membrane phospholipids (Bai et al., 2002; Bai et al., 2004), whereas mutations in the C2B domain $\left(\mathrm{C} 2 \mathrm{~A}-\mathrm{C} 2 \mathrm{~B}^{\star}\right)$ facilitated $\mathrm{Ca}^{2+}$-independent binding of Syt 1 to phospholipids (Mackler et al., 2002). Such differences in $\mathrm{Ca}^{2+}$-independent lipid binding may underlie the differential regulation of spontaneous release in $s y t 1^{-1-}$ mutants rescued with $\mathrm{C} 2 \mathrm{~A}^{*}-\mathrm{C} 2 \mathrm{~B}$ versus $\mathrm{C} 2 \mathrm{~A}-\mathrm{C} 2 \mathrm{~B}^{*}$. Alternatively, neutralizations of these $\mathrm{Ca}^{2+}$-binding residues may induce differential changes in C2 domain structure that influence $\mathrm{Ca}^{2+}$-independent interactions between Syt1 and SNAREs. Syt 1 has been shown to form a $\mathrm{Ca}^{2+}$-independent complex with SNARE proteins in vitro (Bennett et al., 1992; Rickman and Davletov, 2003; Shin et al., 2003) and to stabilize partially assembled trans-SNARE complexes to function as a fusion clamp (Chicka et al., 2008).

Unexpectedly, we found a dramatic enhancement in the rate of spontaneous vesicle release far beyond that observed in syt $1^{-/-}$null mutants when we rescued with transgenic proteins carrying mutations of $\mathrm{Ca}^{2+}$-binding residues in both $\mathrm{C} 2$ domains $\left(\mathrm{C}_{2} \mathrm{~A}^{*}-\mathrm{C} 2 \mathrm{~B}^{\star}\right.$, Fig. 5). Unlike the $\mathrm{Ca}^{2+}$-dependent nature of spontaneous release at mammalian synapses (Xu et al., 2009; Kochubey and Schneggenburger, 2011), $\mathrm{Ca}^{2+}$. dependent changes in mEJP frequency within a compatible 
range (0.2-2.0 mM) of external $\left[\mathrm{Ca}^{2+}\right]$ at Drosophila NMJs has not been observed. As such, how can the dual $\mathrm{Ca}^{2+}$-binding mutations of Syt 1 dramatically alter spontaneous release at Drosophila NMJs? Recently, conformational changes in C2 domain structure associated with $\mathrm{Ca}^{2+}$ binding have been suggested based on crystallization studies (Fuson et al., 2007). Indeed, we observed a change in the size of a protease-sensitive breakdown product previously described for Syt 1 (Littleton et al., 1993) in syt1 ${ }^{-1-}$ null mutants rescued with $\mathrm{C}^{2} \mathrm{~A}^{*}-\mathrm{C} 2 \mathrm{~B}^{*}$ (Fig. 2), suggesting subtle conformational changes in Syt1 structure. $\mathrm{Ca}^{2+}$-binding mutations neutralize negatively charged aspartate residues (i.e., $\mathrm{C}_{2} \mathrm{~A}^{\star}-\mathrm{C} 2 \mathrm{~B}^{\star}$ ), somewhat similar to the effect of bound $\mathrm{Ca}^{2+}$ ions. If these $\mathrm{Ca}^{2+}$-binding mutations in the $\mathrm{C} 2$ domains induce structural changes, it might alter $\mathrm{Ca}^{2+}$-independent interactions between Syt1 and SNARE complexes to increase the frequency of spontaneous vesicle release. It is unlikely that the effect of $\mathrm{C} 2 \mathrm{~A}^{\star}-\mathrm{C} 2 \mathrm{~B}^{\star}$ on $\mathrm{mEJP}$ frequency would be due solely to the rescue of the docking and endocytosis defects observed in $s y t 1^{-1-}$ mutants, as wild-type $\mathrm{C} 2 \mathrm{~A}-\mathrm{C} 2 \mathrm{~B}$ transgenes also rescue these defects but did not induce a dramatic elevation in spontaneous fusion.

\section{Physiological significance of Syt1 multimerization}

Although the Syt family can form multimers in vitro, the relevance of such multimeric complexes on synaptic transmission in vivo has remained unclear. Different Syt family members can form homodimers via their $\mathrm{N}$-terminal cysteine residues in a $\mathrm{Ca}^{2+}$-independent manner (Fukuda et al., 1999; Bai et al., 2000; Fukuda et al., 2001), whereas $\mathrm{Ca}^{2+}$-dependent self-association and formation of heterodimers between different Syt family members are linked to activity of the C2B domain (Chapman et al., 1996; Damer and Creutz, 1996; Sugita et al., 1996; Osborne et al., 1999; Desai et al., 2000). Genetic analyses in Drosophila have suggested Syt oligomerization may regulate synaptic transmission. Mutations in the C2B domain that alter Syt1 oligomerization $\left(S y t^{A D 3}\right)$ (DiAntonio and Schwarz, 1994; Littleton et al., 1994; Fukuda et al., 2000) disrupt synaptic vesicle release (Littleton et al., 2001), although the effects of this mutation on phosphoinositide and SNARE binding, as well as defects in interactions with endocytosis regulators, might also contribute to the inability of the protein to control fusion.

The effects of the $\mathrm{C} 2 \mathrm{~A}^{\star}-\mathrm{C} 2 \mathrm{~B}^{\star}$ transgene on release in the null versus wild-type backgrounds argue that the mutant form of Syt 1 may form multimers with native Syt1 in vivo to generate a complex with unique properties. In the absence of endogenous Syt1, the $\mathrm{C} 2 \mathrm{~A}^{\star}-\mathrm{C} 2 \mathrm{~B}^{\star}$ mutant failed to rescue any aspect of evoked release but strongly activated spontaneous fusion, suggesting that $\mathrm{Ca}^{2+}$-binding defective Syt1 at rest was fusion-prone (Fig. 5). In contrast, when overexpressed with wild-type Syt1, there was no change in $\mathrm{mEJP}$ frequency, indicating that a multimer of native Syt1 and $\mathrm{C}_{2} \mathrm{~A}^{\star}-\mathrm{C} 2 \mathrm{~B}^{\star}$ Syt 1 may be able to effectively clamp spontaneous release (Fig. $7 B$ ). In addition, this complex would be able to dramatically enhance evoked release (Fig. 7A). We hypothesize that overexpression of $\mathrm{C} 2 \mathrm{~A}^{\star}-\mathrm{C} 2 \mathrm{~B}^{\star}$ allows this fusogenic version of Syt1 to multimerize with endogenous Syt1 in both $\mathrm{Ca}^{2+}$ independent and $\mathrm{Ca}^{2+}$-dependent manners in vivo, as suggested by binding assays (Fig. 9). These heteromultimers exhibit characteristics of both Syt1 molecules: they are more effective in $\mathrm{Ca}^{2+}$-dependent vesicle fusion, as evidenced by increased release probability (Fig. 7D) and $\mathrm{Ca}^{2+}$ sensitivity (Fig. $7 C$ ) while maintaining a clamping function provided by endogenous Syt1 to reduce $\mathrm{Ca}^{2+}$-independent spontaneous fusion (compare Figs. $7 B$
5). Although additional studies will be required to confirm that the multimeric Syt1 complex exists in vivo, our data indicate that the different modes of synaptic release, $\mathrm{Ca}^{2+}$-independent spontaneous fusion and $\mathrm{Ca}^{2+}$-dependent synchronous vesicle release, are likely to be regulated by multimerization of Syt1. In addition, our findings provide evidence that both C2 domains of Syt1 are uniquely required for the two forms of synaptic neurotransmitter release.

\section{References}

Bai J, Earles CA, Lewis JL, Chapman ER (2000) Membrane-embedded synaptotagmin penetrates cis or trans target membranes and clusters via a novel mechanism. J Biol Chem 275:25427-25435. CrossRef Medline

Bai J, Wang P, Chapman ER (2002) C2A activates a cryptic $\mathrm{Ca}\left({ }^{2+}\right)$ triggered membrane penetration activity within the $\mathrm{C} 2 \mathrm{~B}$ domain of synaptotagmin I. Proc Natl Acad Sci U S A 99:1665-1670. CrossRef Medline

Bai J, Wang CT, Richards DA, Jackson MB, Chapman ER (2004) Fusion pore dynamics are regulated by synaptotagmin ${ }^{\star}$ t-SNARE interactions. Neuron 41:929-942. CrossRef Medline

Bennett MK, Calakos N, Scheller RH (1992) Syntaxin: a synaptic protein implicated in docking of synaptic vesicles at presynaptic active zones. Science 257:255-259. CrossRef Medline

Brand AH, Perrimon N (1993) Targeted gene expression as a means of altering cell fates and generating dominant phenotypes. Development 118 : 401-415. Medline

Brose N, Petrenko AG, SüdhofTC, Jahn R (1992) Synaptotagmin: a calcium sensor on the synaptic vesicle surface. Science 256:1021-1025. CrossRef Medline

Campos AR, Rosen DR, Robinow SN, White K (1987) Molecular analysis of the locus elav in Drosophila melanogaster: a gene whose embryonic expression is neural specific. EMBO J 6:425-431. Medline

Chapman ER, Davis AF (1998) Direct interaction of a $\mathrm{Ca}^{2+}$-binding loop of synaptotagmin with lipid bilayers. J Biol Chem 273:13995-14001. CrossRef Medline

Chapman ER, Jahn R (1994) Calcium-dependent interaction of the cytoplasmic region of synaptotagmin with membranes: autonomous function of a single C2-homologous domain. J Biol Chem 269:5735-5741. Medline

Chapman ER, Hanson PI, An S, Jahn R (1995) $\mathrm{Ca}^{2+}$ regulates the interaction between synaptotagmin and syntaxin 1. J Biol Chem 270:2366723671. CrossRef Medline

Chapman ER, An S, Edwardson JM, Jahn R (1996) A novel function for the second C2 domain of synaptotagmin. $\mathrm{Ca}^{2+}$-triggered dimerization. J Biol Chem 271:5844-5849. CrossRef Medline

Chicka MC, Hui E, Liu H, Chapman ER (2008) Synaptotagmin arrests the SNARE complex before triggering fast, efficient membrane fusion in response to $\mathrm{Ca}^{2+}$. Nat Struct Mol Biol 15:827-835. CrossRef Medline

Damer CK, Creutz CE (1994) Synergistic membrane interactions of the two C2 domains of synaptotagmin. J Biol Chem 269:31115-31123. Medline

Damer CK, Creutz CE (1996) Calcium-dependent self-association of synaptotagmin I. J Neurochem 67:1661-1668. CrossRef Medline

Desai RC, Vyas B, Earles CA, Littleton JT, Kowalchyck JA, Martin TF, Chapman ER (2000) The C2B domain of synaptotagmin is a $\mathrm{Ca}\left({ }^{2+}\right)$-sensing module essential for exocytosis. J Cell Biol 150:1125-1136. CrossRef Medline

DiAntonio A, Schwarz TL (1994) The effect on synaptic physiology of synaptotagmin mutations in Drosophila. Neuron 12:909-920. CrossRef Medline

Earles CA, Bai J, Wang P, Chapman ER (2001) The tandem C2 domains of synaptotagmin contain redundant $\mathrm{Ca}^{2+}$ binding sites that cooperate to engage t-SNAREs and trigger exocytosis. J Cell Biol 154:1117-1123. CrossRef Medline

Fernandez I, Araç D, Ubach J, Gerber SH, Shin O, Gao Y, Anderson RG, Südhof TC, Rizo J (2001) Three-dimensional structure of the synaptotagmin 1 C2B-domain: synaptotagmin 1 as a phospholipid binding machine. Neuron 32:1057-1069. CrossRef Medline

Fernández-Chacón R, Shin OH, Königstorfer A, Matos MF, Meyer AC, Garcia J, Gerber SH, Rizo J, Südhof TC, Rosenmund C (2002) Structure/ function analysis of $\mathrm{Ca}^{2+}$ binding to the $\mathrm{C} 2 \mathrm{~A}$ domain of synaptotagmin 1 . J Neurosci 22:8438-8446. Medline

Fukuda M, Kanno E, Mikoshiba K (1999) Conserved N-terminal cysteine 
motif is essential for homo- and heterodimer formation of synaptotagmins III, V, VI, and X. J Biol Chem 274:31421-31427. CrossRef Medline

Fukuda M, Kabayama H, Mikoshiba K (2000) Drosophila AD3 mutation of synaptotagmin impairs calcium-dependent self-oligomerization activity. FEBS Lett 482:269-272. CrossRef Medline

Fukuda M, Kanno E, Ogata Y, Mikoshiba K (2001) Mechanism of the SDSresistant synaptotagmin clustering mediated by the cysteine cluster at the interface between the transmembrane and spacer domains. J Biol Chem 276:40319-40325. CrossRef Medline

Fuson KL, Montes M, Robert JJ, Sutton RB (2007) Structure of human synaptotagmin $1 \mathrm{C} 2 \mathrm{AB}$ in the absence of $\mathrm{Ca}^{2+}$ reveals a novel domain association. Biochemistry 46:13041-13048. CrossRef Medline

Geppert M, Goda Y, Hammer RE, Li C, Rosahl TW, Stevens CF, Südhof TC (1994) Synaptotagmin I: a major $\mathrm{Ca}^{2+}$ sensor for transmitter release at a central synapse. Cell 79:717-727. CrossRef Medline

Geppert M, Goda Y, Stevens CF, Südhof TC (1997) The small GTP-binding protein Rab3A regulates a late step in synaptic vesicle fusion. Nature 387:810-814. CrossRef Medline

Haucke V, De Camilli P (1999) AP-2 recruitment to synaptotagmin stimulated by tyrosine-based endocytic motifs. Science 285:1268-1271. CrossRef Medline

Herrick DZ, Sterbling S, Rasch KA, Hinderliter A, Cafiso DS (2006) Position of synaptotagmin I at the membrane interface: cooperative interactions of tandem C2 domains. Biochemistry 45:9668-9674. CrossRef Medline

Hui E, Bai J, Chapman ER (2006) $\mathrm{Ca}^{2+}$-triggered simultaneous membrane penetration of the tandem C2-domains of synaptotagmin I. Biophys J 91:1767-1777. CrossRef Medline

Hui E, Gaffaney JD, Wang Z, Johnson CP, Evans CS, Chapman ER (2011) Mechanism and function of synaptotagmin-mediated membrane apposition. Nat Struct Mol Biol 18:813-821. CrossRef Medline

Jorgensen EM, Hartwieg E, Schuske K, Nonet ML, Jin Y, Horvitz HR (1995) Defective recycling of synaptic vesicles in synaptotagmin mutants of Caenorhabditis elegans. Nature 378:196-199. CrossRef Medline

Kochubey O, Schneggenburger R (2011) Synaptotagmin increases the dynamic range of synapses by driving $\mathrm{Ca}(2)+$-evoked release and by clamping a near-linear remaining $\mathrm{Ca}(2)+$ sensor. Neuron 69:736-748. CrossRef Medline

Lee J, Ueda A, Wu CF (2008) Pre- and post-synaptic mechanisms of synaptic strength homeostasis revealed by Slowpoke and Shaker $\mathrm{K}+$ channel mutations in Drosophila. Neuroscience 154:1283-1296. CrossRef Medline

Littleton JT, Bellen HJ, Perin MS (1993) Expression of synaptotagmin in Drosophila reveals transport and localization of synaptic vesicles to the synapse. Development 118:1077-1088. Medline

Littleton JT, Stern M, Perin M, Bellen HJ (1994) Calcium dependence of neurotransmitter release and rate of spontaneous vesicle fusions are altered in Drosophila synaptotagmin mutants. Proc Natl Acad Sci U S A 91:10888-10892. CrossRef Medline

Littleton JT, Bai J, Vyas B, Desai R, Baltus AE, Garment MB, Carlson SD, Ganetzky B, Chapman ER (2001) Synaptotagmin mutants reveal essential functions for the $\mathrm{C} 2 \mathrm{~B}$ domain in $\mathrm{Ca}^{2+}$-triggered fusion and recycling of synaptic vesicles in vivo. J Neurosci 21:1421-1433. Medline

Liu H, Dean C, Arthur CP, Dong M, Chapman ER (2009) Autapses and networks of hippocampal neurons exhibit distinct synaptic transmission phenotypes in the absence of synaptotagmin I. J Neurosci 29:7395-7403. CrossRef Medline

Llinás R, Steinberg IZ, Walton K (1981) Relationship between presynaptic calcium current and postsynaptic potential in squid giant synapse. Biophys J 33:323-351. CrossRef Medline

Mackler JM, Drummond JA, Loewen CA, Robinson IM, Reist NE (2002) The $\mathrm{C}(2) \mathrm{B} \mathrm{Ca}\left({ }^{2+}\right)$-binding motif of synaptotagmin is required for synaptic transmission in vivo. Nature 418:340-344. CrossRef Medline

Martin AR (1955) A further study of the statistical composition on the endplate potential. J Physiol 130:114-122. Medline

Neher E, Zucker RS (1993) Multiple calcium-dependent processes related to secretion in bovine chromaffin cells. Neuron 10:21-30. CrossRef Medline

Nicholson-Tomishima K, Ryan TA (2004) Kinetic efficiency of endocytosis at mammalian CNS synapses requires synaptotagmin I. Proc Natl Acad Sci U S A 101:16648-16652. CrossRef Medline

Nishiki T, Augustine GJ (2004a) Dual roles of the C2B domain of synap- totagmin I in synchronizing $\mathrm{Ca}^{2+}$-dependent neurotransmitter release. J Neurosci 24:8542-8550. CrossRef Medline

Nishiki T, Augustine GJ (2004b) Synaptotagmin I synchronizes transmitter release in mouse hippocampal neurons. J Neurosci 24:6127-6132. CrossRef Medline

Osborne SL, Herreros J, Bastiaens PI, Schiavo G (1999) Calcium-dependent oligomerization of synaptotagmins I and II: synaptotagmins I and II are localized on the same synaptic vesicle and heterodimerize in the presence of calcium. J Biol Chem 274:59-66. CrossRef Medline

Paddock BE, Striegel AR, Hui E, Chapman ER, Reist NE (2008) $\mathrm{Ca}^{2+}$ dependent, phospholipid-binding residues of synaptotagmin are critical for excitation-secretion coupling in vivo. J Neurosci 28:7458-7466. CrossRef Medline

Paddock BE, Wang Z, Biela LM, Chen K, Getzy MD, Striegel A, Richmond JE, Chapman ER, Featherstone DE, Reist NE (2011) Membrane penetration by synaptotagmin is required for coupling calcium binding to vesicle fusion in vivo. J Neurosci 31:2248-2257. CrossRef Medline

Pang ZP, Shin OH, Meyer AC, Rosenmund C, Südhof TC (2006a) A gainof-function mutation in synaptotagmin-1 reveals a critical role of $\mathrm{Ca}^{2+}$ dependent soluble N-ethylmaleimide-sensitive factor attachment protein receptor complex binding in synaptic exocytosis. J Neurosci 26: 12556-12565. CrossRef Medline

Pang ZP, Sun J, Rizo J, Maximov A, Südhof TC (2006b) Genetic analysis of synaptotagmin 2 in spontaneous and $\mathrm{Ca}^{2+}$-triggered neurotransmitter release. EMBO J 25:2039-2050. CrossRef Medline

Perin MS, Fried VA, Mignery GA, Jahn R, Südhof TC (1990) Phospholipid binding by a synaptic vesicle protein homologous to the regulatory region of protein kinase C. Nature 345:260-263. CrossRef Medline

Perin MS, Brose N, Jahn R, Südhof TC (1991) Domain structure of synaptotagmin (p65). J Biol Chem 266:623-629. Medline

Poskanzer KE, Marek KW, Sweeney ST, Davis GW (2003) Synaptotagmin I is necessary for compensatory synaptic vesicle endocytosis in vivo. Nature 426:559-563. CrossRef Medline

Reist NE, Buchanan J, Li J, DiAntonio A, Buxton EM, Schwarz TL (1998) Morphologically docked synaptic vesicles are reduced in synaptotagmin mutants of Drosophila. J Neurosci 18:7662-7673. Medline

Rickman C, Davletov B (2003) Mechanism of calcium-independent synaptotagmin binding to target SNAREs. J Biol Chem 278:5501-5504. CrossRef Medline

Robinson IM, Ranjan R, Schwarz TL (2002) Synaptotagmins I and IV promote transmitter release independently of $\mathrm{Ca}\left({ }^{2+}\right)$ binding in the $\mathrm{C}(2) \mathrm{A}$ domain. Nature 418:336-340. CrossRef Medline

Rodal AA, Blunk AD, Akbergenova Y, Jorquera RA, Buhl LK, Littleton JT (2011) A presynaptic endosomal trafficking pathway controls synaptic growth signaling. J Cell Biol 193:201-217. CrossRef Medline

Sabatini BL, Regehr WG (1996) Timing of neurotransmission at fast synapses in the mammalian brain. Nature 384:170-172. CrossRef Medline

Shao X, Davletov BA, Sutton RB, Südhof TC, Rizo J (1996) Bipartite $\mathrm{Ca}^{2+}$ binding motif in $\mathrm{C} 2$ domains of synaptotagmin and protein kinase $\mathrm{C}$. Science 273:248-251. CrossRef Medline

Shin OH, Rhee JS, Tang J, Sugita S, Rosenmund C, Südhof TC (2003) $\mathrm{Sr}^{2+}$ binding to the $\mathrm{Ca}^{2+}$ binding site of the synaptotagmin $1 \mathrm{C} 2 \mathrm{~B}$ domain triggers fast exocytosis without stimulating SNARE interactions. Neuron 37:99-108. CrossRef Medline

Shin OH, Xu J, Rizo J, Südhof TC (2009) Differential but convergent functions of $\mathrm{Ca}^{2+}$ binding to synaptotagmin-1 C2 domains mediate neurotransmitter release. Proc Natl Acad Sci U S A 106:16469-16474. CrossRef Medline

Stevens CF, Sullivan JM (2003) The synaptotagmin C2A domain is part of the calcium sensor controlling fast synaptic transmission. Neuron 39: 299-308. CrossRef Medline

Striegel AR, Biela LM, Evans CS, Wang Z, Delehoy JB, Sutton RB, Chapman ER, Reist NE (2012) Calcium binding by synaptotagmin's C2A domain is an essential element of the electrostatic switch that triggers synchronous synaptic transmission. J Neurosci 32:1253-1260. CrossRef Medline

Südhof TC, Rizo J (1996) Synaptotagmins: C2-domain proteins that regulate membrane traffic. Neuron 17:379-388. CrossRef Medline

Sugita S, Hata Y, Südhof TC (1996) Distinct Ca $\left({ }^{2+}\right)$-dependent properties of the first and second C2-domains of synaptotagmin I. J Biol Chem 271:1262-1265. CrossRef Medline

Sun JY, Wu LG (2001) Fast kinetics of exocytosis revealed by simultaneous 
measurements of presynaptic capacitance and postsynaptic currents at a central synapse. Neuron 30:171-182. CrossRef Medline

Sutton RB, Davletov BA, Berghuis AM, SüdhofTC, Sprang SR (1995) Structure of the first $\mathrm{C} 2$ domain of synaptotagmin I: a novel $\mathrm{Ca}^{2+}$ / phospholipid-binding fold. Cell 80:929-938. CrossRef Medline

Sutton RB, Ernst JA, Brunger AT (1999) Crystal structure of the cytosolic C2A-C2B domains of synaptotagmin III: implications for $\mathrm{Ca}(+2)$ independent snare complex interaction. J Cell Biol 147:589-598. CrossRef Medline

Tucker WC, Weber T, Chapman ER (2004) Reconstitution of $\mathrm{Ca}^{2+}$ regulated membrane fusion by synaptotagmin and SNAREs. Science 304: 435-438. CrossRef Medline

Ubach J, Zhang X, Shao X, Südhof TC, Rizo J (1998) $\mathrm{Ca}^{2+}$ binding to synaptotagmin: how many $\mathrm{Ca}^{2+}$ ions bind to the tip of a C2-domain? EMBO J 17:3921-3930. CrossRef Medline

Voets T, Moser T, Lund PE, Chow RH, Geppert M, Südhof TC, Neher E (2001) Intracellular calcium dependence of large dense-core vesicle exocytosis in the absence of synaptotagmin I. Proc Natl Acad Sci U S A 98: 11680-11685. CrossRef Medline

Wojcik SM, Brose N (2007) Regulation of membrane fusion in synaptic excitation-secretion coupling: speed and accuracy matter. Neuron 55:11-24. CrossRef Medline
Xu J, Pang ZP, Shin OH, Südhof TC (2009) Synaptotagmin-1 functions as a $\mathrm{Ca}^{2+}$ sensor for spontaneous release. Nat Neurosci 12:759-766. CrossRef Medline

Yao J, Kwon SE, Gaffaney JD, Dunning FM, Chapman ER (2012a) Uncoupling the roles of synaptotagmin I during endo- and exocytosis of synaptic vesicles. Nat Neurosci 15:243-249. CrossRef Medline

Yao LH, Rao Y, Varga K, Wang CY, Xiao P, Lindau M, Gong LW (2012b) Synaptotagmin 1 is necessary for the $\mathrm{Ca}^{2+}$ dependence of clathrinmediated endocytosis. J Neurosci 32:3778-3785. CrossRef Medline

Yoshihara M, Littleton JT (2002) Synaptotagmin I functions as a calcium sensor to synchronize neurotransmitter release. Neuron 36:897-908. CrossRef Medline

Yoshihara M, Guan Z, Littleton JT (2010) Differential regulation of synchronous versus asynchronous neurotransmitter release by the C2 domains of synaptotagmin 1. Proc Natl Acad Sci U S A 107:1486914874. CrossRef Medline

Young SM Jr, Neher E (2009) Synaptotagmin has an essential function in synaptic vesicle positioning for synchronous release in addition to its role as a calcium sensor. Neuron 63:482-496. CrossRef Medline

Zhang X, Kim-Miller MJ, Fukuda M, Kowalchyk JA, Martin TF (2002) $\mathrm{Ca}^{2+}$-dependent synaptotagmin binding to SNAP-25 is essential for $\mathrm{Ca}^{2+}$-triggered exocytosis. Neuron 34:599-611. CrossRef Medline 